\title{
Pension Fund Asset Allocation and Liability Discount Rates: Camouflage and Reckless Risk Taking by U.S. Public Plans?
}

\author{
Aleksandar Andonov \\ Maastricht University \\ Rob Bauer \\ Maastricht University \\ Martijn Cremers \\ Yale University
}

May 2012

\begin{abstract}
We use an international pension fund database to compare the asset allocation and liability discount rates of public and non-public funds in the U.S., Canada and Europe. We document that U.S. public funds exploit the opaque incentives provided by their distinct regulatory environment and behave very differently from U.S. corporate funds and both public and non-public pension funds in Canada and Europe. In the past two decades, U.S. public funds uniquely increased their allocation to riskier investment strategies in order to maintain high discount rates and present lower liabilities, especially if their proportion of retired members increased more. In line with economic theory, all other groups of pension funds reduced their allocation to risky assets as they mature, and lowered discount rates as riskless interest rates declined. The arguably camouflaging and risky behavior of U.S. public pension plans seems driven by the conflict of interest between current and future stakeholders, and could result in significant costs to future workers and taxpayers.
\end{abstract}

JEL classification: G11, G18, G23, H55.

Keywords: pension funds, public, asset liability management, asset allocation, liability discount rates, retired, mature, regulation.

\footnotetext{
Acknowledgements

Contact authors via email at a.andonov@maastrichtuniversity.nl, r.bauer@maastrichtuniversity.nl and martijn.cremers@yale.edu (changes to mcremers@nd.edu after June 2012). We thank CEM Benchmarking Inc. in Toronto for providing us with the CEM database. For helpful comments and suggestions, we thank Keith Ambachtsheer, Dirk Broeders, Jeffrey Brown, Theo Kocken, Ranji Nagaswami and Peter Schotman. We gratefully acknowledge research funding provided by the Rotman International Centre for Pension Management at the Rotman School of Management, University of Toronto (ICPM). All errors are our own.
} 


\section{Introduction}

Pension funds around the world are in a state of flux. In the past two decades, funds have been confronted with financial crises, tightening regulation, a maturing participant base, decreasing treasury yields and increasing demands for transparency and accountability. Moreover, most defined benefit (DB, which guarantee benefits to members) funds are underfunded and have fewer assets than the pension promises they made, despite the fact that the valuation of the size of these liabilities in many cases is severely underestimated (see Novy-Marx and Rauh (2011)).

The challenge for the members of the Board of Trustees of DB pension funds - in conjunction with other stakeholders - is how to decide and periodically update critical aspects of their fund's policy, such as the contribution levels of plan members, strategic allocations across various asset classes and the kind of inflation protection offered, using projections of their liabilities (i.e., pension promises) and their expected future income from investments. When considering their fund's asset-liability management, these boards need to decide on a few key inputs such as the level of expected returns, interest and inflation rates, and on the discount rate used to value the liability stream, as well as on a number of actuarial indicators.

The amount of latitude boards have in this process depends on the regulatory framework in which they operate. In general, these decisions could be left at the full discretion of the pension funds, or, at the other side of the spectrum, be heavily restricted by regulation or public policy. Previous literature (see e.g. Novy-Marx and Rauh (2009, 2011) and Brown and Wilcox (2009)) has shown that regulation pertaining to U.S. public pension DB plans is relatively opaque and leaves wide discretion to their boards. As a first contribution of this paper, we provide a comparison of their regulatory framework to that of other pension funds internationally, and argue that regulations for U.S. public funds are special, setting them apart from Canadian and European public pension funds as well as from corporate pension funds in all three of the regions for which we have data (i.e., U.S., Canada and Europe).

U.S. public funds seem distinct in that they can decide their strategic asset allocations and liability discount rates largely without much regulatory interference, due to wide latitudes allowed in the currently applicable Government Accounting Standards Board (GASB) guidelines. In particular, these guidelines link the liability discount rates of U.S. public funds to the (assumed) expected rate of returns of the assets, rather than to the riskiness of the liabilities as suggested by economic theory. As a result, funds can maintain higher liability discount rates even in an era of low interest rates by holding more assets with higher assumed 
expected returns. In contrast, U.S. corporate funds and (both public and non-public) Canadian and European pension funds are arguably subject to significantly stricter regulatory guidelines. Especially in the second decade of our sample, their regulators typically monitor closely or (implicitly) restrict the proportion of investments that can be made in specific risky asset classes. Furthermore, their regulations generally also proscribe how liability discount rates should be chosen, typically as a function of current interest rates (see e.g. Canadian Institute of Actuaries (2011) and Crossley and Jametti (2011)).

The main contribution of this paper is to empirically document that U.S. public DB funds have responded very differently to two critical and on-going developments that are exogenous to individual pension fund boards and that have profound economic implications: maturing client populations and falling government bond yields. While all other funds adapt their asset allocations and liability discount rates to changes in maturity and interest rates in a way that is broadly in line with economic theory (see e.g. Sundaresan and Zapatero (1997) and Lucas and Zeldes (2009)), U.S. public funds do not. We argue that their behavior is consistent with their incentives and is facilitated by the distinct regulatory environment pertaining to U.S. public pension funds.

For each of these two critical exogenous developments, the main results are as follows. The first major issue is the increased maturity of pension funds, i.e., that the percentage of members (current or past workers who are beneficiaries) who are retired has increased as a fraction of all members. Economic theory suggests that asset allocations and liability discount rate choices should be more conservative as the fund matures (see Lucas and Zeldes (2006, 2009), Sundaresan and Zapatero (1997), and Benzoni, Collin-Dufresne and Goldstein (2007)). We find that this is indeed how funds have generally responded. U.S. public funds are unique in not choosing more conservative asset allocations and not choosing lower discount rates as their client base matures. Instead, for U.S. public funds the proportion of retirees relative to non-retirees is positively related to the allocation to risky assets, with a 10 percentage point increase in the proportion of retired members being associated with an increase in the allocation to risky assets of more than one percentage point. Similarly, in sharp contrast to the other funds in our sample, U.S. public funds have increased their liability discount rates while their funds matured.

The second major development is that interest rates have significantly declined over our time period in each of the three regions we consider. The main theoretical prediction relates to the choice of the liability discount rate. Financial theory suggests that future streams of pension payments should be discounted at a 
rate that reflects their inherent riskiness and in particular their covariance with priced risks. Beneficiaries of pension promises, for both public and corporate entities, are quite well protected by law, such that these pension payments are relatively certain or bear relatively little systemic risk (see e.g. Brown (2008) and Brown and Wilcox (2009)). ${ }^{1}$ As a result, Brown and Wilcox (2009) and Novy-Marx and Rauh (2011) propose using liability discount rates based on yields on government and municipal bonds and swap rates.

Empirically, we find that funds generally lower their liability discount rates as interest rates decline. However, U.S. public funds are again different, as for them we find no association between liability discount rates and interest rates. In contrast to the other funds, the typical policy of U.S. public funds is to set their liability discount rate equal to the expected return of the asset portfolio, where they have great latitude to posit what those expected returns are. This suggests another interpretation of the lack of any association between the level of interest rates and the liability discount rates of U.S. public funds, namely that U.S. public pension funds have made the economically surprising choice of not lowering their expected return estimates on risky assets as interest rates decline. This would further suggest that the problem of underestimated liabilities as documented in Novy-Marx and Rauh (2011) has become more severe as interest rates have declined.

We also study the decision to provide contractual inflation protection. We document that public pension funds (especially in the U.S.) are more likely to promise inflation-indexed pensions to their participants. Brown and Wilcox (2009) argue that funds that promise inflation protection should use risk-free real interest rates (TIPS) to discount their pension promises. However, we find no association between liability discount rates and whether or not the DB fund offers inflation protection. This indicates that funds may be underestimating the costs of their inflation protection promises.

In summary, our results suggest that over the last 20 years U.S. public funds uniquely increased their allocation to riskier investment strategies in order to maintain high discount rates and present lower liabilities, especially if their proportion of retired members increased more. These decisions by the boards of U.S. public DB pension funds have large economic effects and could have potentially severe future consequences. At the beginning of our sample, U.S. public funds had liability discount rates and allocations to risky assets that were similar to the other funds in our sample. By the end of our time period in 2010, U.S.

\footnotetext{
${ }^{1}$ For public funds, pension promises in U.S. are usually backed by constitutional non-impairment clauses as well as through statutory and common law (Brown and Wilcox (2009)). The Pension Benefit Guarantee Corporation backs pension promises of corporate defined benefit plans in the U.S. Even if a firm enters bankruptcy with insufficient pension assets to cover its liabilities to workers, plan participants will still receive their annual pensions up to a statutory maximum amount.
} 
public funds as a group had the highest discount rates (190 basis points above the U.S. corporate funds and even more above typical discount rates of Canadian and European funds) as well as the largest allocations to risky assets (average of $73.4 \%$; U.S. corporate funds have an average of $65.7 \%$, while Canadian and European funds have even lower allocation to risky assets).

This behavior can be explained by the basic conflict of interest between current and future stakeholders of U.S. public pension funds. Current stakeholders, including boards, members and their representatives as well as politicians and taxpayers, have a direct incentive to underestimate the current value of the existing liabilities and transfer this risk to future generations. In this era of general underfunding, this will allow current members to receive higher benefits without boards and politicians having to make tougher choices now. ${ }^{2}$ Likewise, the GASB rules linking liability discount rates to the riskiness of the assets creates incentives to invest in more risky assets in order to keep liability discount rates high.

We discuss policy implications, where our main focus is on bringing U.S. public fund regulation in line with regulation typically applying to U.S. corporate funds and (either public or corporate) Canadian / European funds. We argue that the current regulatory framework pertaining to U.S. public pension funds provides the wrong incentives: plans that are underfunded can adopt riskier investment strategies that enable them to use higher discount rates and present lower liabilities in the official measures of pension funding status. This increased risk-taking allows them to camouflage their actual funding levels and postpone greater public scrutiny or taxpayer support. However, they run the considerable risk that these more volatile investments do not perform according to the assumed expected rates of return. As a result, a major worry is that their increased risk-taking is reckless and could lead to substantial future costs to taxpayers or public entities. Similarly, the lack of any association between liability discount rates and contractual inflation protection (which applies particularly to U.S. public funds) raises the worry that these funds may underestimate the costs of these promises which, eventually, can become future taxpayers' burden.

\footnotetext{
${ }^{2}$ A recent example can illustrate the economic magnitude. The actuary of CalPERS recommended lowering the liability discount rate from 7.75\% to 7.25\%, according to a news article (Bloomberg News, March 7, 2012, "CalPERS Should Cut Assumed Return to 7.25\% From 7.75\%, Actuary Recommends”). That article states: "Lowering the return would boost the state's employee pension costs, as a percent of payroll, as much as 4.2 percent in the year beginning July 1 , according to a CalPERS staff report. Local governments could see an increase of as much as 4.5 percent the following year. The costs for some public-safety agencies could jump as much as 6.5 percent. ... The board rejected a similar proposal ... last year. Board members at the time expressed concern that lowering the rate to 7.5 percent would burden local governments when they were already facing financial strains.” One week later (see "CalPERS Lowers Investment Target to 7.5\%,” Wall Street Journal, March 14, 2012), the CalPERS board decided to indeed lower the discount rate, but by only half as much as recommended by its actuary.
} 
We employ the unique international CEM database that contains detailed information on pension fund maturity, liability discount rates and inflation indexation policy (all previously unexplored) as well as on not just the actual allocations across many detailed asset classes, but also their long-term strategic asset allocation weights (which change only every few years on average and are thus unaffected by short-term market movements) as approved by the pension boards. CEM collects asset allocation data at a deaggregated level (i.e., within broad asset classes like fixed income, many different investments are separately identified), which enables us to directly measure the riskiness of the asset allocation policy. Finally, the database covers three regions (U.S., Canada and Europe) and thereby allows us to compare public versus non-public pension funds across different international regulatory environments.

Our main results come from comparing U.S. public funds to public funds in Europe (mainly funds from the U.K. and the Netherlands) and Canada, as well as to corporate funds in all three regions. The new results for Canadian and European funds suggest that public and corporate funds behave similarly when they face a similar regulatory environment. The relatively long time series and broad cross-sectional coverage provides strong statistical power, such that our main results are derived in pooled panel regressions with pension fund fixed effects as well as year fixed effects, using robust standard errors that are independently double-clustered in both the time and fund dimensions.

Compared to other pension funds datasets such as the IRS 5500 Filings from the Department of Labor and the Center for Retirement Research (CRR), the CEM database thus offers an exclusive viewpoint on the asset-liability management of pension funds around the globe. CEM data has been used previously by e.g. French (2008) to study the cost of active investing, and by Andonov, Bauer and Cremers (2011) to examine the asset allocation, market timing and security selection skills of pension funds. ${ }^{3}$

The remainder of the paper is organized as follows. In section 2, we briefly discuss the predictions from economic theory and from the incentives created by a regulatory framework allowing for significant discretion on the part of U.S. pension fund boards. Section 3 discusses the database we use and provides some summary statistics. In section 4, we explain the methodology employed. The empirical results are discussed in section 5 and section 6 concludes with a discussion of policy implications, including the recent

\footnotetext{
${ }^{3}$ Other papers studying pension fund performance using the CEM database are Bauer, Cremers and Frehen (2010), Dyck and Pomorski (2011) and Andonov, Eichholtz and Kok (2012). Our findings are in line with the predictions of Brown and Wilcox (2009) and Lucas and Zeldes (2009) that accounting rules for U.S. public pension funds create a perverse incentive to invest more in riskier assets in order to discount liabilities at a higher rate. We confirm this prediction by documenting that over time and as a group, U.S. public funds (have) become the biggest risk-takers among pension funds around the globe. Our findings on U.S. corporate funds are in line with Rauh (2009), who also documents a positive correlation between risk taking and the share of active employees in the corporate pension plans.
} 
GASB (2011) proposals - pertaining only to U.S. public funds - that would severe the link between liability discount rates and expected rates of returns but only for funds that can be classified as underfunded.

\section{Optimal asset allocation and regulation of pension funds}

In this section, we explain the predictions about the risk-taking behavior and the choice of the liability discount rates of pension funds (and how these relate to fund maturity and interest rates) from two different perspectives. We first consider economic theory, and then possible short-term incentives in the context of underfunded defined benefit pension plans and regulation. Risk-taking behavior means the proportion of assets invested in risky assets, such as public equity, private equity, real estate and alternative assets. The liability discount rate refers to the rates that are used by the pension funds to discount their projections of future pension payments. In our empirical section, we test these predictions about how the level of interest rates, plan maturity and contractual inflation protection relate to the allocation to risky assets and the liability discount rate.

\subsection{The relation between risk taking, fund maturity and inflation protection}

Theoretical models imply that the optimal asset allocation should be a function of fund maturity, salary growth and promised inflation protection. In principle, these variables should have similar effects across all funds, regardless of geographical region, regulatory requirements and plan type (public or corporate).

First, economic theory and empirical work argue that the correlation between returns on risky assets and the growth in average aggregate labor earnings are positively correlated in the long-run, although shortrun correlation is typically low. Lucas and Zeldes (2006) show theoretically that when labor earnings growth and stock returns are positively correlated over longer horizons, obligations to older workers and retirees behave more like bonds and can be valued and hedged as such. However, because of future salary risk, obligations to younger workers are risky or behave more like stocks. As a result, Sundaresan and Zapatero (1997) and Lucas and Zeldes (2009) argue that the proportion of pension fund assets invested in risky assets should be positively related to the percentage of active participants, as pension benefits are tied to salaries, which are positively correlated with stock returns in the long-run. 
Rauh (2009) finds a positive correlation between risk taking and the share of active employees in U.S. corporate pension plans, whereas Lucas and Zeldes (2009) find a positive, but statistically insignificant coefficient on the share of active participants among U.S. public funds. Compared to this prior research, we can examine not only the cross-sectional dimension, but also how allocations to risky assets have changed over a relatively long and dynamic time period. Moreover, we can incorporate international evidence on public as well as corporate pension plans. For instance, the sample in Lucas and Zeldes (2009) consists of 109 state and 87 local plans in a single year (2006), whereas Rauh (2009) focuses only on U.S. corporate funds. Our sample includes 804 public and corporate defined benefit pension funds in three regions over a 20-year period.

Further, Campbell and Viceira (2005) argue that optimal pension fund asset allocation also depends on the contractual indexation policy, i.e., whether the liabilities are fixed in real or nominal terms, and show that holding bonds to maturity is akin to accumulating inflation risk. Boudoukh and Richardson (1993) and Schotman and Schweitzer (2000) document that stocks can serve as an inflation hedge in the long run.

Regarding the appropriate rates to discount the pension liabilities, financial theory suggests that the streams of future pension payments should be discounted at a rate that reflects the inherent risk of these cash flows, and in particular their covariance with priced risks. In the case of pension funds, the 'risk' associated with the liabilities relates primarily to whether the promised benefits will be paid in full in the future. For public funds, pension promises in U.S. are usually backed by constitutional non-impairment clauses as well as through statutory and common law (Brown and Wilcox (2009)). Pension promises of corporate defined benefit plans in the U.S. are backed by the Pension Benefit Guarantee Corporation. If a firm enters bankruptcy with insufficient pension assets to cover its liabilities to workers, the U.S. government provides plan recipients with their annual pensions up to a statutory maximum amount. In addition, underfunded corporate plans have to contribute a deficit reduction (“catch-up”) contribution. ${ }^{4}$ Hence, pension promises of both public and corporate funds are well protected, such that there is little uncertainty about whether the promised benefits will have to be paid. As a result, Brown and Wilcox (2009) and Novy-Marx and Rauh (2011) propose using treasury rates, municipal rates and swap rates to discount pension liabilities, because these rates reflect the low uncertainty pertaining to the promised pension payments.

\footnotetext{
${ }^{4}$ Brown (2008) presents the examples of Bethlehem Steel, US Airways and other companies with underfunded defined benefit pension funds and discusses flaws in the pension insurance system.
} 
The implication that follows is that liability discount rates should decrease in line with decreasing government bond yields. Further, as the yield curve is generally upward sloping, we would expect that more mature pension funds, i.e. plans whose liabilities have shorter durations, should typically use lower discount rates than younger funds. Furthermore, public pension funds should use lower discount rates than corporate funds, as benefits of public plans are virtually free of risk as they are usually backed by constitutional guarantees, while members of private plans still risk losing part of their pensions if the firm enters bankruptcy.

\subsection{How pension fund regulation affects asset allocation decisions and liability discount rates}

We examine the effect of differences in pension fund regulation by contrasting the regulatory framework for U.S. public funds with that pertaining to U.S. corporate funds and both public and corporate pension funds in Canada and Europe. Specifically, we argue that these regulatory differences give rise to different incentives about the choice of the proportion of assets invested in risky asset classes and the liability discount rate used. The main difference across funds consists of regulations of the liability discount rates. U.S., Canadian and European funds generally face few limits on the proportion of investments they can make in risky assets (see the OECD 2011 Survey of Investment Regulation of Pension Funds).

In the U.S., significant differences in regulation exist between corporate and public pension plans. U.S. public pension funds are subject to the Government Accounting Standards Board (GASB) guidelines for discounting liabilities. These guidelines allow U.S. public funds to base their liability discount rates on the expected rate of returns on their assets. As U.S. public fund boards are largely unconstrained in the proportion of their assets that can be invested in risky assets and in their assumptions on the expected rate of return in the various asset classes, this gives these boards very significant latitude to choose their liability discount rate. In particular, we argue that U.S. public funds have considerably more latitude in their choices than U.S. corporate funds or (public or corporate) funds in Canada and Europe.

Novy-Marx and Rauh (2009, 2011) and Brown and Wilcox (2009) argue that this latitude gives rise to strong incentives to invest more in risky assets that can be assumed to have higher expected rates of return. The resulting higher liability discount rates allow the public funds to present lower liability estimates and better funding status, even though the nature of their liabilities remains the same. In times that public

funds are typically severely underfunded (even using their relatively high liability discount rates), this 
relieves pressure, at least in the short term, on the public entities involved, as well as on (again temporarily) politicians and taxpayers.

Despite the critiques from academic economists, GASB still maintains the view that "as long as plan assets related to current employees, retirees, and their beneficiaries are projected to be sufficient to make the projected benefit payments for those individuals, governments would discount projected benefit payments using the long-term expected rate of return” (GASB (2011)). Ambachtsheer (2010) argues that under this GASB rule, pension obligations will continue to be underfunded and underreported in U.S. public sector pension plans. Novy-Marx (2011) shows that under this rule it is possible that a plan can improve its official measure of funding status by literally burning money. ${ }^{5}$

Using time series data on the trends in strategic asset allocations over the last 20 years, we are able to test directly whether U.S. public pension funds use their freedom strategically. When facing decreasing bond yields, their typical discount rates of around seven to eight percent can only be maintained by allocating even more assets to equity and alternatives. This riskier allocation can thereby camouflage the level of underfunding. This camouflage of pension underfunding amplifies the risk that DB plans will run out of assets before they run out of liabilities, which would involve a significant wealth transfer from future to current generations of workers and taxpayers.

Pennacchi and Rastad (2011) document that state pension plans gamble by choosing a riskier portfolio following periods of relatively poor investment performance. We extend this analysis by associating changes in asset allocation to changes in fund maturity and government yields, contrasting U.S. public funds to U.S. corporate funds and international public and corporate pension funds, and over long time horizon (1990-2010).

Using yields on taxable municipality and treasury bonds, i.e. discount rates that reflect the very limited uncertainty of future public pension fund payments, Novy-Marx and Rauh (2011) show that all state pension plans in the U.S. are severely underfunded in 2009. The collective underfunding is in the range of \$1.26-2.49 trillion. Hence, all public funds in U.S. are tempted to continue to use high discount rates even when interest rates decline, to present a more favorable situation to beneficiaries, taxpayers and creditors.

\footnotetext{
${ }^{5}$ Novy-Marx (2011) shows that GASB penalizes a plan for holding cash and bonds, by forcing it to recognize a larger liability if they do so: "By destroying a dollar's worth of T-bills, or other cash-equivalents, a manager decreases a plan's assets, but increases the remaining assets' expected returns. These higher expected returns are used as a discounting rate and decrease the present value of plan's liability, as recognized by GASB, and this decrease can more than offset the loss of assets” (Novy-Marx (2011)). In the conclusion, we discuss the recent GASB (2011) proposals - pertaining only to U.S. public funds - that would severe the link between liability discount rates and expected rates of returns but only for funds that can be classified as underfunded.
} 
Within the public U.S. funds, we expect that funds with a greater percentage of retired members have especially strong incentives to use higher discount rates, as the shorter maturity increases the present value of their liabilities and limits their ability to camouflage their underfunding. Hence, we expect that more mature public funds in the U.S. are using higher discount rates.

U.S. corporate funds face different regulatory standards and do not have clear incentives to invest more in riskier assets over time. Rauh (2009) shows that the risk management incentives to avoid costly financial distress dominate risk-shifting incentives in corporate defined benefit pension funds (especially amid tightening regulation). However, Love, Smith and Wilcox (2011) argue that various forms of government intervention, such as benefit guarantees, can alter this outcome dramatically by providing the firm with an incentive to shift risk to other parties.

Most importantly for our empirical identification, individual firms in the U.S. have less discretion over their reported pension liabilities and discounting rates compared to public funds. In particular, until 2004 U.S. firms were required to discount their liabilities, for funding purposes and the estimation of the deficit reduction (“catch-up”) contributions, using the 30-year Treasury rate. Since 2006 firms are allowed to discount their liabilities using a discount rate that is a blend of long-term corporate bonds, including both upper-medium and high-grade securities (Rauh (2006)).

At the same time, let us emphasize that we are making a comparison, and are not arguing that U.S. corporate plans had no regulatory latitude at all. For example, Brown (2008) presents examples of ways in which accounting standards that existed prior to the Pension Protection Act of 2006 allowed firms to hide the true economic costs of pension promises. ${ }^{6}$ Since 2006, their asset-liability management has been subject to more regulatory scrutiny. Moreover, firms have also incentives to use appropriate discount rates and shore up underfunded pension plans, as firms that are sufficiently overfunded are exempt from the Pension Benefit Guaranty Corporation (PBGC) insurance premiums, and pension overfunding reduces the probability of a rating downgrade in such a way that the value of the firm is increased (Rauh (2006) and Bergstresser, Desai and Rauh (2006)).

\footnotetext{
${ }^{6}$ For instance, prior to the adoption of Pension Protection Act of 2006 firms were only required to fund 90 percent of their liabilities, were permitted to "smooth" interest rates over four years (which allowed firms to report smaller liabilities in periods of declining interest rates), were allowed to use the smoothed "actuarial" value rather than the market value of plan assets (with up to a 20 percent deviation from actual market values permitted), and were allowed to avoid making cash contributions to their pension plan by making use of various accounting credits even if the plan was underfunded. The Pension Protection Act of 2006 addressed these issues by e.g. mandating minimum contribution rules that, after a phase-in period, are based on 100 percent, rather than 90 percent funding, of a plan's liabilities, and the time period for smoothing assets and liabilities was reduced to two years (Brown (2008)).
} 
In Canada, pension fund accounting standards generally require that the discount rate be selected based on market yields of high-quality corporate debt instruments with cash flows that match the timing and amount of expected benefit payments. These standards seem to leave only limited room for discretion, primarily in any latitude allowed on what "high quality" exactly means, which specific debt instruments are to be included, and how to address the lack of suitable debt instruments at very longer-term maturities (Canadian Institute of Actuaries (2011)).

Furthermore and in sharp contrast to the U.S., Canadian public and corporate pension plans are regulated in the same way, generally under the domain of the financial market supervisors of the Province where they are registered. In Canada, only the province of Ontario (where around 50 percent of the plans are registered) has established pension benefit insurance. Crossley and Jametti (2011) find that insured plans in Canada invest about 5 percent more in equities than do similar plans without benefit guarantees. We do not have information on the province where Canadian funds are registered, but we control for fund fixed effects, which should absorb the differences in asset allocation due to such cross-jurisdiction variation.

Our small sample of European funds consists almost entirely of Dutch pension funds (plus a few from the U.K.). In the Netherlands, pension funds have almost no discretion in choosing their liability discount rate. Until 2004, Dutch pension funds were obliged to use $4 \%$ as their discounting rate. Afterwards, the Financial Assessment Framework (FTK), which is part of the Pensions Act, set the requirements to discount the liabilities with the term structure (swap-curve) of nominal risk-free interest rates (or real in case of inflation indexation guarantees). In this tight regulatory regime, poorly funded funds are less inclined to invest in riskier assets. If there is a funding shortfall (i.e., coverage ratio less than 105\%), the fund must submit a recovery plan. The coverage ratio must regain the 105\% level within 3 years. In the U.K., corporate plans discount their liabilities using AA yields, whereas public funds use a 3.0\% discount rate, set based on the expected GDP growth in the long run.

\section{Data}

We can study the linkage between pension fund asset allocation and liabilities in a way that allows the consideration of both cross-sectional relations and relations within plans over time. We have access to the unique international CEM dataset, comprised of more than 800 defined benefit pension funds for the 19902010 period. The CEM database provides a detailed perspective on the pension fund strategic (or target) 
asset allocations on a lower aggregation level. This detailed information enables us to precisely estimate the riskiness of the strategic asset allocation policy. Moreover, we can provide international evidence and examine the effect of different regulatory standards on the pension fund asset allocation, as our data covers three regions (U.S., Canada and Europe).

On the liabilities side, the dataset provides information on the maturity of the fund, the indexation policy, and the liability discount rates. The dataset contains information on the number of active and retired plan members, which enables us to infer the percentage of retired members. We use the percentage of retired members as a proxy of fund maturity. The database also provides information on the characteristics of the indexation policy, e.g. whether a fund provides full, ad hoc or no inflation protection. CEM also collects the discount rates that pension funds use to calculate the present value of the liabilities.

On the assets side, we especially focus on the percentage allocation to risky assets based on the reported strategic asset allocation policy. Every year, pension funds submit their target asset allocation policy and their actual (realized) asset allocation policy to CEM. In practice, the actual asset allocation policy can be affected by market movements due to expected transaction costs of rebalancing or investors inertia. For example, large positive returns on the equity market will increase the share of this asset class in the pension fund's actual asset allocation. Hence, in order to avoid the effects from market movements and to capture more precisely the decision of pension fund boards with respect to asset allocation, we focus on the strategic (target) asset allocation policy. ${ }^{7}$

We define the percentage allocation to risky assets as allocation to equity, alternative asset classes and riskier fixed income investments. Alternative asset classes incorporate allocations to real estate, private equity, hedge funds, commodities, natural resources, infrastructure and tactical asset allocation mandates. We classify mortgages and high yield mandates as risky fixed income investments. The non-risky assets include investments in cash and investment-grade fixed income assets.

In our empirical analysis, we also split the sample into public and non-public pension funds. The non-public subsample captures the funds classified as 'corporate' and 'other' in the CEM database. In the U.S. and Canada, the 'other' category is mainly composed of multi-employer or Taft-Hartley funds, often referred to as ‘union' funds. In Europe, the 'other' category covers mainly industry-wide funds, which are common in the Netherlands. We combine the category 'other' with 'corporate' and label this group 'non-

\footnotetext{
${ }^{7}$ All our results are robust to using the risky assets estimated based on the actual asset allocation policy instead of the strategic asset allocation.
} 
public' funds, because these funds are established by private sector employers and they are subject to the same regulation. For example, in the U.S., the multi-employer private defined benefit pension plans, like the single-employer the Employee Retirement Income Security Act (ERISA), regulates plans, and they have an insurance program within the Pension Benefit Guaranty Corporation.

Table 1 presents the summary statistics of the pension funds in our sample. Panel A shows that pension funds on average allocate $65.1 \%$ of their assets to risky investments. There is no significant difference between the public and corporate (non-public) funds, but there are regional effects. U.S. funds are on average allocating a greater percentage of their assets to riskier investments (68.3\%) as compared to Canadian (60.5\%) and European (57.1\%) funds.

Panel B of Table 1 shows fund maturity summary statistics estimated based on the percentage of retired members. On average, retired members account for $38.7 \%$ of total members. Non-public funds are more mature with $40.7 \%$ retired members as compared to public funds with $34.7 \%$ retired members. The

difference in maturity between public and corporate funds arises because a growing number of U.S. corporations have chosen to freeze defined benefit (DB) pension plans and replace them with defined contribution (DC) plans for new employees (see Rauh, Stefanescu and Zeldes (2011)). Hence, corporate DB pension plans in the U.S. mature faster than public funds. Among Canadian and European funds there are no differences in the percentage of retired members between public and non-public funds.

We present the summary statistics of liability discount rates in Panel C of Table 1. U.S. pension funds are using higher discount rates (7.4) compared to Canadian (6.8) and, especially, compared to European (3.8) funds. Among U.S. funds, public funds are using on average higher rates to discount their liabilities (7.8) as compared to corporate funds (7.2).

\section{Methodology}

The standard deviations of our three main variables in Table 1 show that there is considerable variation in the allocation to risky assets, fund maturity and liability discount rates among the pension funds in our sample. In order to investigate the relation between the key variables of interest, we implement a regression analysis, using pooled panel regressions with year and regional or fund fixed effects.

We first focus on the percentage allocation to risky assets based on the strategic asset allocation policy (\%Risky) as a dependent variable. We estimate the following regression: 


$$
\% \text { Risky }_{i, t}=\beta_{1} \% \text { Ret }_{i, t}+\beta_{2} \text { Size }_{i, t}+\beta_{3} \text { InfProt }_{i, t}+\beta_{4} \text { Public }_{i}+\gamma Y D_{t}+c_{i}+u_{i, t}
$$

$\%$ Ret refers to the percentage retired members and Size is the logarithm of the US\$ value of assets under management of fund $i$ in year $t$. Inf Prot is a dummy variable taking value one if fund $i$ in year $t$ provides contractual inflation protection and zero otherwise. Public is a dummy variable taking value one if a pension fund is public and zero if the fund is non-public. $Y D$ is the year dummy, $c_{i}$ captures regional or fund-fixed effects and $u_{i, t}$ is the idiosyncratic error. We independently double cluster the robust standard errors in all regressions by pension fund and by year. In the regressions we include also interaction terms to capture the effect of public U.S. funds, as the group with significantly different regulation.

During our sample period, 1990-2010, the treasury yields in all regions continuously declined. ${ }^{8}$ In order to investigate whether these decreasing treasury yields have an effect on the allocation to risky assets, we also add the ten-year treasury yield in the previous year to the model presented in equation (1).

Further, we focus on the liability discount rates $(L D R)$ as a dependent variable:

$$
\% L D R_{i, t}=\beta_{1} \% \text { Risky }_{i, t}+\beta_{2} \% \operatorname{Ret}_{i, t}+\beta_{3} \text { Size }_{i, t}+\beta_{4} \operatorname{InfProt}_{i, t}+\beta_{5} \text { Public }_{i}+\gamma Y D_{t}+c_{i}+u_{i, t}
$$

Brown and Wilcox (2009) and Novy-Marx and Rauh (2011) argue that liability discount rates should be based on the nominal or real treasury yields. Furthermore, Novy-Marx and Rauh (2011) find that the effective average duration of U.S. public state funds over the range of various discount rates is roughly 13 years. Hence, to estimate the effect of treasury yields on liability discount rates, we use the yield on ten-year Treasury notes in U.S., Canada and Europe. We use the ten-year treasury rate, because the fifteen-year treasury rate is not available in all region covered by our study and in our estimations we are focused on the trend in treasury yield, which is highly correlated across treasury yields of different maturities. We estimated the following extended version of model (2):

$$
\% L D R_{i, t}=\beta_{1} \operatorname{TrYield}_{t}+\beta_{2} \% \text { Risky }_{i, t}+\beta_{3} \% \text { Ret }_{i, t}+\beta_{4} \text { Size }_{i, t}+\beta_{5} \text { InfProt }_{i, t}+\beta_{6} \text { Public }_{i}+c_{i}+u_{i, t}
$$

\footnotetext{
${ }^{8}$ For example, the ten-year treasury yields in U.S. declined from 8.55 percent in 1990 to 3.22 percent in 2010.
} 
where $\operatorname{TrYield}_{t}$ represents the U.S., Canadian or European ten-year treasury yields in year $t$.

We also estimate the probability whether a pension fund provides a contractual inflation protection. To answer this question we use a binary response logit model:

$$
\operatorname{Pr}\left(\text { InfProt }_{i, t}\right)=f\left(\% \text { Ret }_{i, t}+\text { Size }_{i, t}+\text { Public }_{i}+\text { Region }_{i}+\gamma Y D_{t}\right)
$$

where $f$ is the logit function taking on values strictly between zero and one. Finally, in all regressions we consider the important of regional fixed effects (i.e., dummies for Canada and Europe) as well as pension fund fixed effects.

\section{Results}

We first explore how the allocation to risky assets is related to fund characteristics. Next, we analyze the association of the percentage of investments allocated to risky assets and the fund maturity with the liability discount rates used to determine the value of the liabilities. Finally, we investigate the decision to provide contractual inflation protection. As explained in section 4, the pooled panel data regressions include year fixed effects as well as regional or fund-fixed effects, and use robust standard errors double-clustered independently both by fund and by year.

\subsection{Pension fund maturity and risk taking}

Figure 1 presents the average percentage retired members and the percentage of investments allocated to risky assets, by region and plan type (i.e., public versus non-public pension funds). Panel A of Figure 1 shows that non-public funds in the U.S. are more mature when compared to public funds, while for both groups the percentage of retired members has increased considerably. The allocation to risky assets among U.S. public funds increases steadily over time, while among corporate funds it is rather stable until 2004 and decreasing thereafter. As a result, U.S. corporate funds invest more in risky assets during 19922005 than U.S. public funds, but that is reversed for 2006-2010. Panel B of Figure 1 indicates that there is no difference in the percentage of retired members of public and corporate pension funds in Canada. In Europe, the sample is much smaller, but again we find no clear difference between public and corporate funds. 
Table 2 presents the results of the allocation to risky assets panel regressions jointly for U.S., Canadian and European funds. Column (1) indicates that more mature funds, with a higher proportion of retired members, invest less in risky assets in line with theoretical predictions. An increase in the percentage of retired members by 10 percent points is associated with a reduction in the allocation to risky assets of 0.79 percent points, controlling for fund size, the level of inflation protection and regional and year fixed effects. Controlling for fund-fixed effects in column (6), an increase in the percentage of retired members by 10 percent points is associated with a reduction in the allocation to risky assets of 1.31 percent points.

Pension funds with more assets under management (i.e., with larger 'fund size') allocate proportionally more assets to risky investments. In particular, a one-unit increase in the log of asset under management (i.e., doubling the pension fund size) increases the allocation to risky assets from 0.5-0.9 percent points. The effect of fund size on the allocation to risky assets is not significant when controlling for fund-fixed effects in columns 6 - 8. This may be no surprise, as fund-fixed effects remove considerable variation and assets under management do not vary strongly over time (especially relative to the large crosssectional variation in size and taking out year fixed effects). The decision to provide contractual inflation protection does not seem related to the asset allocation policy.

In column 2, we add a 'Public' dummy indicating whether the pension fund is public or not, in order to estimate the effect of plan type (public or non-public) on the strategic asset allocation policy. Public pension funds allocate 3.2 percent points less to risky assets, on average. Column (5) and (8) show that U.S. public funds behave different. In contrast to other funds, more mature U.S. public funds allocate more to risky assets. The positive relation between fund maturity and risk taking is not consistent with the negative relation that is predicted by economic theory and found as the average coefficient in the overall sample in columns 1-8. For all funds except U.S. public pension funds, a 10 percentage points increase in the percentage of retired members is associated with a 1.16 percentage point $(0.1 *(-0.116)=0.0116)$ lower allocation to risky assets (column 5). However, a 10 percent points increase in the percentage of retired members of U.S public funds (column (5)) is associated with a 2.05 percent points increase in the allocation to risky assets $(0.1 *(-0.116)+0.1 * 0.321=0.0205)$. The magnitude is slightly smaller, but still positive and significant, when controlling for fund-fixed effects in column (8).

The large negative coefficients on the dummies for Canadian and European funds indicate significant regional differences in the allocation to risky assets, that seem unrelated to incorporating 
differences for U.S. public funds (comparing column (1) to columns (2) - (5)). Controlling for maturity, fund size and plan type, U.S. funds allocate around 8 percentage points more to risky assets than Canadian funds, and 14 percentage points more than European funds.

The main conclusion from Table 2 is that more mature funds generally allocate fewer assets to risky investments, the only exception being U.S. public pension funds. Contrary to the predications from economic theory that maturing funds should reduce their exposure to risky assets, we find that mature U.S. public pension funds allocate a greater percentage of their assets to risky investments.

In Table 3, we analyze the relation between fund maturity and risk-taking for every region separately. ${ }^{9}$ We find a significant negative relation, on average, between fund maturity and risk taking in the U.S. and the Canadian sample. For U.S. funds (see Panel A, columns (3) and (7)), we find that a 10 percent points increase in fund maturity is associated with a reduction of the allocation to risky assets of $1.43-1.76$ percentage points among non-public (i.e., corporate) funds. However, for U.S. public funds this relation is positive. In particular, a 10 percent points increase in the percentage of retired members is associated with an increase of the allocation to risky assets of a U.S. public pension fund by 2.31 percentage points $(0.1 *(-$ $0.143)+0.1 * 0.374$, see column (3)). When controlling for fund-fixed effects, a 10 percent points increase in the percentage retired members is associated with an increase of the allocation to risky assets of a U.S. public fund by 1.10 percentage points (column 5).

Results for Canada (Panel B of Table 3) show that an increase of 10 percent points in fund maturity reduces the allocation to risky assets by $0.8-0.9$ percentage points. Whether a plan is corporate or public seems unrelated to the strategic asset allocation policy of Canadian pension funds. Public and corporate pension funds in Canada are also reducing their exposure to risky assets in a similar way as they mature.

During 1990-2010, yields on government bonds continuously declined in all regions (see Figure 2). For example, the yield on ten-year U.S. Treasury notes decreased from $8.55 \%$ in 1990 to $3.22 \%$ in 2010 . Table 4 examines whether declining yields, as a proxy for the expected return on non-risky assets like cash and government bonds, influence the allocation to risky assets by pension funds. Our results indicate that only public funds, and especially U.S. public funds, increased their allocation to risky assets as a response to declining government bond yields. A one percentage point decline in the yield on ten-year government securities in the previous year is associated with a 2.6 percentage point increase in the allocation to risky

\footnotetext{
${ }^{9}$ We do not show results for European funds separately due to its limited sample size.
} 
assets among Canadian and European public funds, and a 3.9 percentage point increase in risk-taking among U.S. public funds.

Controlling for fund-fixed effects in columns (5) - (8), the differential association remains significant only for U.S. public funds (see column (8)). According to column (8), for U.S. public funds a one percentage point decline in the yield on ten-year Treasury securities in the previous year is associated with a 2.8 percentage points increase in the allocation to risky assets $(-1 *(-0.010)+(-1) *(-0.018))$. This finding is robust to controlling for the percentage of retired members in columns (4) and (8).

Summarizing, we show that more mature funds invest less in risky assets, the only exception being U.S. public pension funds. Moreover, especially these funds take more risk in response to declining government bond yields. The increased risk-taking by U.S. public funds when faced with low interest rates is particularly remarkable as U.S. public funds have even less ability (relative to e.g. U.S. corporate funds) to scale back spending if risky assets underperform expectations, as their benefits are often given special protections in state constitutions as well as through statutory and common law (Brown and Wilcox (2009)).

\subsection{Liability discount rates}

This subsection explores whether the liability discount rates reported to CEM are related to certain pension fund characteristics. We focus on the relation of fund maturity, asset allocation and government bond yields with the discount rate used by pension funds to value their liabilities.

Results in Table 5 show that the allocation to risky assets is positively related to the liability discount rates. In column (1), a 10 percent points increase in the allocation to equity, alternative assets and riskier fixed income assets is associated with an increase of the liability discount rate of six basis points. Controlling for fund-fixed effects in column (8), this economic magnitude goes up to nine basis points. Further, in columns (1) and (8) we observe that more mature pension funds are using lower discount rates, which is in line with economic theory. For example, a 10 percent points increase in the percentage of retired members is associated with a reduction of the liability discount rate of seven basis points (column 8).

We observe substantial regional differences in the liability discount rates. Canadian pension funds are using rates to discount their liabilities that are 30.9-58.6 basis points lower as compared to U.S. funds. European funds are using liability discount rates more than 300 basis points lower relative to their U.S. counterparts (consistent with regulatory differences). 
Whether a pension fund is public or corporate has a very strong effect on the liability discount rate in the U.S. Column (3) indicates that U.S. public funds are typically using discount rates that are 64 basis points higher than U.S. corporate funds. In Canada and Europe, plan type is not affecting the liability discount rates, i.e. in those regions public and corporate funds are behaving in a similar way (see the insignificant coefficient on the 'Public' dummy in column (3), (5) and (7)).

U.S. public funds that allocate a greater percentage of their assets to risky investments tend to use higher liability discount rates (column (5)). Surprisingly, an even more important determinant of the liability discount rate among U.S. public pension funds is fund maturity. Contrary to what economic theory would predict, more mature public pension funds in the U.S. are using even higher discount rates. Based on column (7), a 10 percentage point increase in the percentage of retired members is associated with a reduction of the discount rates of three basis points among corporate funds in U.S. and all fund types in other regions. However, the interaction term \%Retired * Public * U.S. is positive and statistically significant. Hence, based on column (7), for public U.S. funds a 10 percent points increase in the percentage of retired members is associated with an increase of the discount rate by 21 basis points $(0.1 *(-0.299)+0.1 * 2.393)$. Controlling for fund-fixed effects in column (12), this economic magnitude increases to 31 basis points.

In summary, our results show that pension funds that invest in riskier assets on average use higher rates to discount their liabilities. More mature funds in Europe, Canada and more mature corporate funds in the U.S. use lower liability discount rates. However, more mature public pension funds in the U.S. are, contrary to expectations, using the highest discount rates during the 1990-2010 period.

Brown and Wilcox (2009) and Novy-Marx and Rauh (2011) argue that the liability discount rates should be based on the nominal (or real, if inflation protection is offered) government bond yields, municipal interest rates or swap rates. Thus, we examine whether the liability discount rates follow the trend in ten-year treasury yields (consistent with the duration of liabilities). Figure 2 displays the trend in government bond yields and liability discount rates of public and non-public regions, separately for each region. Consistent with the results in Table 5, U.S. pension funds are using higher rates to discount their liabilities. Among U.S. funds, public funds are maintaining steady discount rates around $7.5-8.0$ percent. In sharp contrast, the liability discount rates used by U.S. corporate funds are decreasing over time, closely following the pattern in ten-year Treasury yields. The discount rates used by Canadian pension funds are also decreasing over time, but not as much as the Canadian government bond yield. Most European funds use fixed discount rates of 
four percent before 2000, following strict regulatory guidelines. Afterwards, these guidelines are relaxed a bit and their liability discount rates move together with the government bond yields. In both Europe and Canada, there is no significant difference between the discount rates used by public and corporate pension funds.

In Table 6, we estimate the effect of government bond yields on the liability discount rates using pooled panel regressions. We document that pension fund discount rates respond to changes in yields. The average response is less than proportional, as a 100 basis point decrease in the ten-year government bond yield results in a decrease in the liability discount rates of around $30-40$ basis points. Even when controlling for treasury yields, the percentage of retired members remains negative and significant, especially when controlling for fund-fixed effects. More mature pension funds are using lower discount rates regardless of the trend in yields. The percentage allocation to risky assets also remains positive and significant.

In line with the trend in Panel A of Figure 2, the discount rates used by U.S. public pension funds are not responding to changes in Treasury yields. The triple interaction Public * Yield * U.S. is negative and significant, outweighing completely the unconditional effect of treasury yield on discount rates. Based on column (8) with fund fixed effects, a 100 basis points decrease in the government bond yield reduces the discount rate by 29.7 basis points on average among corporate funds in U.S. and all fund types in other regions. However, Treasury yield changes have no discernible effects on the liability discount rates of U.S. public funds, as a 100 basis point decrease in the Treasury yield reduces the discount rates by around four basis points only $(1 * 0.297+1 *(-0.251))$, which is not significantly different from zero.

Next, we perform a robustness check to examine the relation between liability discount rates and pension fund characteristics by region. Results in columns (1) to (4) in Table 7 indicate that corporate funds in the U.S. use lower liabilities discount rates when Treasury yields decrease. More mature corporate pension funds in the U.S. are using also significantly lower discount rates. Consistent with Table 6, public pension funds in the U.S. are behaving in the opposite way. We find no such differences between public and nonpublic funds for Canada in columns 5 - 8. Overall, the results indicate that U.S. public funds are not only using higher discount rates if they are more mature, but also that U.S. public funds do not take into account the changes in Treasury yields when determining their discount rates, contrary to economic theory.

Instead, regulations allow U.S. public funds to set their liability discount rate equal to the expected return of the asset portfolio, where they have great latitude to posit what those expected returns are. As a 
result, another interpretation of the lack of any association between the level of interest rates and the liability discount rates of U.S. public funds is that U.S. public pension funds have made the economically surprising choice of not lowering their expected return estimates on risky assets as interest rates decline.

\subsection{Inflation protection}

Next, we estimate the probability that a pension fund provides contractual inflation protection to its participants. We model these probabilities as a function of pension fund characteristics, focusing on fund maturity, fund size and plan type (public or non-public).

Our results in Table 8 indicate that the likelihood that public funds provide contractual inflation protection is significantly higher than for non-public funds. Results in column (2) show that the probability that a non-public fund provides contractual inflation protection is 17.0 percent, whereas the probability for public pension funds is 58.7 percent. Column (3) shows that U.S. public funds have the highest probability to provide inflation protection among the pension funds in our sample.

In columns (1) and (2) of Table 8, we also document that funds with a greater percentage of retired members are less likely to provide contractual inflation protection. For instance, based on column (2), the probability to provide contractual inflation protection for funds with 27 percent retired members $\left(25^{\text {th }}\right.$ percentile) is 32.0 percent. This probability decreases to 25.9 percent for funds that have 48 percent retired members $\left(75^{\text {th }}\right.$ percentile). Fund maturity has a negative effect on the probability to provide contractual inflation protection by U.S. funds (the relation is negative, but insignificant among Canadian funds).

The negative relation between the percentage of retired members and the decision to provide contractual inflation protection indicates that 'younger' pension funds may overpromise to their plan members. The risk younger cohorts face is that, once pension funds mature and face funding difficulties in delivering the promised benefits, contractual inflation protection may be removed from the pension deal. Eliminating the contractual inflation protection is one of the measures of last resort available to underfunded pension funds, but its implementation is difficult especially in the U.S. context, as pension benefit promises have strong protections.

Furthermore, even after controlling for fund maturity, size and plan type, the likelihood that Canadian funds provide inflation protection is significantly higher. Our results also indicate that, in Canada, larger funds are more likely to provide inflation protection. Based on columns (8), (9) and (10), a one unit 
increase in the logarithm of assets under management (i.e., doubling the fund size) increases the probability that a Canadian pension fund provides contractual inflation protection by 11.9-13.2 percent.

In the previous section, we showed that public pension funds use substantially higher liabilities discount rates. The results in Table 8 indicate that public pension funds are more generous as they are more likely to promise contractual inflation protection to their beneficiaries. Brown and Wilcox (2009) argue that, if a pension fund promises inflation protection, then their liabilities should be discounted using real interest rates, i.e., inflation-indexed rates based on the Treasury Inflation-Protected Securities (TIPS). Hence, public pension funds do not only ignore the trends in Treasury yields, but also the promised inflation protection to their beneficiaries when determining the liability discount rates.

\section{Conclusion}

In this paper, we employ a comprehensive dataset of U.S., Canadian and European public and corporate defined benefit pension funds and investigate their asset allocation, liability discount rates and contractual inflation protection over the last two decades. We find that U.S. public pension funds behave different from all other pension funds and not in line with economic theory. We ascribe their different reaction to the maturing of their participant base and declining government bond yields to opaque incentives arising from their distinct regulatory framework that gives U.S. public pension funds wider discretion to choose their liability discount rates than U.S. corporate funds and both public and private pension funds in Canada and Europe.

Generally, more mature pension funds invest less in risky assets and use lower discount rates for the valuation of their liabilities. Canadian and European public and private funds, as well as corporate pension funds in the U.S., base their liability discount rates on high quality interest rates. This does not create incentives for these funds to increase the allocation to risky assets over time. However, U.S. public pension funds are allowed to base their discount rates on the expected rate of return of their asset portfolio, which provides them with incentives to take more risk over time in response to declining government bond yields. Taking more risk thus enables public pension funds in the U.S. to maintain high discount rates and present more favorable funding ratios to the public, despite the fact that this does not in any way alter the nature of their liabilities. For public U.S. funds, we document that funds with a greater percentage of retired members 
use even higher discount rates, possible because the shorter maturity increases the present value of their liabilities and limits their ability to camouflage their underfunding.

In conclusion, we show that the regulatory framework may have a substantial impact on the strategic decisions made by pension funds. We provide evidence that the distinct behavior of U.S. public pension plans is consistent with their more lax regulatory context, which may provide the wrong incentives. In times of severe underfunding or political distress, the incentives are strong to not lower discount rates sufficiently in response to lower interest rates and a maturing client base, at the same time adopting (perhaps recklessly) risky asset allocation strategies and camouflaging the real costs of pension promises made to their beneficiaries and taxpayers. As a result, their regulation allows a potentially severe conflict of interest between current and future stakeholders.

Gradually, U.S. public funds have become the biggest risk-takers among pension funds around the globe, especially if they are more mature or the proportion of their members that is retired increased more. These funds are thus exposed to very large market risk. At the same time, U.S. public funds have almost no ability to scale back spending if risky assets underperform expectations, as their benefits are often given special protections in state constitutions as well as through statutory and common law (Brown and Wilcox (2009)). Hence, a major worry is that their increased risk-taking is reckless and could lead to substantial future costs to taxpayers or public entities if their more volatile risky investments fail to meet the expected rates of return. Moreover, the lack of any association between liability discount rates and contractual inflation protection (which applies particularly to U.S. public funds) raises the concern that these funds may underestimate even more the costs of these promises. This raises the possibility that U.S. public funds are camouflaging the real costs of pension promises made to their beneficiaries and taxpayers. The economic consequences of these practices could involve material wealth transfers from future taxpayers and workers to current pensioners and workers (see also Kocken (2012)).

The policy implications are clear but challenging. The purpose of public and corporate defined benefit pension plans is the same, i.e., providing a secure and affordable pension to their members. There seems to be no good economic reason why public and corporate funds in the U.S. should be regulated in a different way. When corporate and public funds are regulated in a similar way, i.e., in Canada and Europe, their behavior does not differ. Our findings indicate that in a highly politicized setting and a tough economic environment for pension funds in general, U.S. public pension funds willingly made strategic decisions to 
significantly increase risk and camouflage the value of their promised pension benefits. These decisions may have a large negative impact for future stakeholders and taxpayers. In sum, we argue that U.S. policy pertaining to public pension funds needs drastic reform and to be brought in line with regulations pertaining to U.S. corporate pension funds, as current laws and regulations effectively exempt states and cities from behaving prudently in how they manage and disclose the financing of pension systems of their employees.

Recently, the GASB issued new proposals that take a major step in this direction. Specifically, GASB (2011) proposes severing the link between liability discount rates and expected rates of returns but only for funds that can be classified as underfunded, i.e. where the plan assets are not "projected to be sufficient to pay benefits and the net position projected to remain after each benefit payment can be invested long-term.” The GASB notes that for such underfunded funds where "the plan assets are projected not to be available to be invested long-term and, therefore, would be insufficient for paying benefits to current employees, retirees, and their beneficiaries, ... the projected benefit payments take on attributes that are similar to other forms of debt. In this circumstance, governments would incorporate into the discount rate a tax-exempt, high-quality 30-year municipal bond index rate to reflect that future benefit payments are not expected to be made from long-term investments. High quality would be defined as being rated AA or higher (or an equivalent rating).” However, for funds where plan assets are projected to be sufficient, the wrong incentives would remain in place as the assumed rate of returns of the assets could still be used to discount the liabilities. Moreover, these projections (of whether or not assets are sufficient to pay the benefits) can seemingly still be based on liability discount rates that are linked to expected asset returns. As a result, the new GASB proposals would create even stronger incentives to camouflage liabilities and engage in reckless risk-taking for funds that are close to being underfunded (and that may indeed be underfunded if liabilities would be discounted at - currently - lower high-quality municipal yields) and that rationally want to avoid being classified as underfunded. 


\section{References}

Allen, F. (2001): “Presidential Address: Do Financial Institutions Matter?,” The Journal of Finance, 56(4), $1165-1175$.

Ambachtsheer, K. (2010): “GASB’s Folly,” The Ambachtsheer Letter, August.

Andonov, A., R. Bauer, and M. Cremers. (2011): "Can Large Pension Funds Beat the Market? Asset Allocation, Market Timing, Security Selection and the Limits of Liquidity,” Working Paper, Maastricht and Yale University.

Andonov, A., P. Eichholtz, and N. Kok (2012): "Value Added from Money Managers in Private Markets? An Examination of Pension Fund Investments in Real Estate,” Working Paper, Maastricht University.

Benzoni, L., P. Collin-Dufresne, and R. Goldstein (2007): "Portfolio Choice Over the Life-Cycle when the Stock and Labor Markets are Cointegrated”, Journal of Finance, 62(5), 2123-2167.

Bergstresser, D., M. Desai, and J. Rauh (2006): "Earnings manipulation, pension assumptions, and managerial investment decisions,” Quarterly Journal of Economics, 121(1), 157-195.

Boudoukh, J., and M. Richardson (1993): "Stock returns and inflation: a long horizon perspective," American Economic Review, 83, 1346-1355.

Brown, J. (2008): "Guaranteed Trouble: The Economic Effects of the Pension Benefit Guaranty Corporation,” Journal of Economic Perspectives, 22(1), 177-198.

Brown, J., and D. Wilcox (2009): “Discounting State and Local Pension Liabilities,” American Economic Review, 99(2), 538-542.

Campbell, J.Y., and L.M. Viceira (2005): “The term structure of the risk-return trade-off," Financial Analysts Journal, 61, 34-44.

Canadian Institute of Actuaries (2011): “Accounting Discount Rate Assumption for Pension and Postemployment Benefit Plans”, Educational Note, Issued September 20, 2011.

Crossley, T., and M. Jametti (2011): "Pension Benefit Insurance and Pension Plan Portfolio Choice," forthcoming in Review of Economics and Statistics.

Dyck, A. and L. Pomorski (2011): “Is Bigger Better? Size and Performance in Pension Plan Management,” Working Paper, University of Toronto.

French, K. (2008): “Presidential Address: The Cost of Active Investing,” Journal of Finance, 63(4), p.15371573.

Governmental Accounting Standards Board (2011): "Pension Accounting and Financial Reporting, PlainLanguage Supplement to an Exposure Draft.”

Kocken, T. (2012): "Pension Liability Measurement and Intergenerational Fairness,” Rotman International Journal of Pension Management, 5(1).

Love, D.A., P.A. Smith, and D.W. Wilcox (2011): "The effect of regulation on optimal corporate pension risk,” Journal of Financial Economics, 101, 18-35 
Lucas, D., and S.P. Zeldes (2006) "Valuing and Hedging Defined Benefit Pension Obligations: The Role of Stocks Revisited," Working Paper, Northwestern and Columbia University.

Lucas, D. and S.P. Zeldes (2009): "How should public plans invest?,” American Economic Review, 99(2), 527-532.

Novy-Marx, R., and J. Rauh (2009): "The Liabilities and Risks of State-Sponsored Pension Plans." Journal of Economic Perspectives, 23(4), 191-210.

Novy-Marx R. and J. Rauh (2011): "Public Pension Promises: How Big Are They and What Are They Worth?,” The Journal of Finance, 66(4), 1211-1249.

Novy-Marx (2011): “Logical Implications of GASB's Methodology for Valuing Pension Liabilities,” Working Paper, University of Rochester and NBER.

OECD Secretariat (2011): “Survey of Investment Regulation of Pension Funds”, Published June 2011.

Pennacchi, G., and M. Rastad (2011): "Portfolio Allocation of Public Pension Funds,” Journal of Pension Economics and Finance, 10(2), 221-245.

Rauh, J. (2006): "Investment and Financing Constraints: Evidence from the Funding of Corporate Pension Plans,” The Journal of Finance, 61(1), 33-71.

Rauh, J. (2009): "Risk Shifting versus Risk Management: Investment Policy in Corporate Pension Plans,” Review of Financial Studies, 22, 2687-2733.

Rauh, J., I. Stefanescu, and S. Zeldes (2011): “Cost savings and the freezing of corporate pension plans,” Working Paper, Northwestern, Indiana and Columbia University.

Schotman, P.C., and M. Schweitzer (2000): “Horizon sensitivity of the inflation hedge of stocks,” Journal of Empirical Finance, 7, 301-315.

Sundaresan, S., and F. Zapatero (1997): "Valuation, Optimal Asset Allocation and Retirement Incentives of Pension Plans,” Review of Financial Studies, 10, 631-60. 
Table 1: Summary statistics: Pension fund maturity, asset allocation and liability discount rates

This table provides descriptive statistics of pension funds' asset allocation, maturity and liabilities. We show the following statistics: $25^{\text {th }}$ percentile, median, $75^{\text {th }}$ percentile, mean and standard deviation (StDev). Columns \# Funds and \# Obs. present the number of funds and observations. Panel A shows the percentage allocation to risky assets based on the strategic asset allocation policy. Panel B presents the descriptive statistics of the percentage of retired members from total plan members. The risky assets include allocations to equity, alternative asset classes (i.e., hedge funds, private equity and real estate), high yield bonds and mortgages. Panel $\mathrm{C}$ presents the liability discount rates used by the pension funds. We show the statistics for all funds and separately by region. We also show the statistics separately for public and non-public funds.

\begin{tabular}{|c|c|c|c|c|c|c|c|}
\hline & \# Funds & \# Obs. & $25^{\text {th }}$ & Median & $75^{\text {th }}$ & Mean & StDev \\
\hline \multicolumn{8}{|c|}{ Panel A: Summary Statistics - Percentage allocation to risky assets based on strategic asset allocation } \\
\hline All funds & 804 & 4821 & 0.600 & 0.650 & 0.728 & 0.651 & 0.114 \\
\hline - Public & 226 & 1653 & 0.600 & 0.670 & 0.730 & 0.653 & 0.118 \\
\hline - Non-public & 593 & 3168 & 0.600 & 0.650 & 0.725 & 0.650 & 0.112 \\
\hline U.S. & 505 & 2932 & 0.640 & 0.700 & 0.750 & 0.683 & 0.113 \\
\hline - Public & 160 & 1171 & 0.640 & 0.700 & 0.740 & 0.675 & 0.114 \\
\hline - Non-public & 348 & 1761 & 0.650 & 0.700 & 0.750 & 0.689 & 0.112 \\
\hline Canada & 222 & 1621 & 0.550 & 0.600 & 0.650 & 0.605 & 0.089 \\
\hline - Public & 57 & 448 & 0.539 & 0.600 & 0.675 & 0.603 & 0.109 \\
\hline - Non-public & 177 & 1173 & 0.550 & 0.600 & 0.650 & 0.606 & 0.080 \\
\hline Europe & 77 & 268 & 0.505 & 0.584 & 0.651 & 0.571 & 0.135 \\
\hline - Public & 9 & 34 & 0.440 & 0.557 & 0.619 & 0.544 & 0.119 \\
\hline - Non-public & 68 & 234 & 0.512 & 0.588 & 0.655 & 0.575 & 0.138 \\
\hline \multicolumn{8}{|c|}{ Panel B: Summary Statistics - Percentage retired members } \\
\hline All funds & 804 & 4821 & 0.267 & 0.358 & 0.482 & 0.387 & 0.186 \\
\hline - Public & 226 & 1653 & 0.277 & 0.332 & 0.392 & 0.347 & 0.146 \\
\hline - Non-public & 593 & 3168 & 0.257 & 0.393 & 0.526 & 0.407 & 0.201 \\
\hline U.S. & 505 & 2932 & 0.281 & 0.360 & 0.480 & 0.391 & 0.177 \\
\hline - Public & 160 & 1171 & 0.281 & 0.326 & 0.375 & 0.333 & 0.093 \\
\hline - Non-public & 348 & 1761 & 0.281 & 0.418 & 0.550 & 0.430 & 0.207 \\
\hline Canada & 222 & 1621 & 0.245 & 0.351 & 0.489 & 0.381 & 0.202 \\
\hline - Public & 57 & 448 & 0.261 & 0.345 & 0.430 & 0.383 & 0.230 \\
\hline - Non-public & 177 & 1173 & 0.239 & 0.355 & 0.500 & 0.380 & 0.191 \\
\hline Europe & 77 & 268 & 0.239 & 0.387 & 0.468 & 0.372 & 0.182 \\
\hline - Public & 9 & 34 & 0.344 & 0.393 & 0.405 & 0.384 & 0.135 \\
\hline - Non-public & 68 & 234 & 0.230 & 0.385 & 0.471 & 0.371 & 0.189 \\
\hline \multicolumn{8}{|c|}{ Panel C: Summary statistics - Liability discount rates } \\
\hline All funds & 740 & 4666 & 6.250 & 7.250 & 8.000 & 7.033 & 1.308 \\
\hline - Public & 205 & 1597 & 7.000 & 8.000 & 8.000 & 7.411 & 1.178 \\
\hline - Non-public & 550 & 3069 & 6.000 & 7.000 & 7.750 & 6.837 & 1.329 \\
\hline U.S. & 477 & 2865 & 6.740 & 7.750 & 8.000 & 7.415 & 1.101 \\
\hline - Public & 144 & 1129 & 7.750 & 8.000 & 8.160 & 7.776 & 0.964 \\
\hline - Non-public & 336 & 1736 & 6.250 & 7.250 & 8.000 & 7.180 & 1.121 \\
\hline Canada & 208 & 1577 & 6.250 & 7.000 & 7.500 & 6.800 & 0.995 \\
\hline - Public & 54 & 441 & 6.000 & 6.750 & 7.380 & 6.707 & 0.957 \\
\hline - Non-public & 166 & 1136 & 6.250 & 7.000 & 7.500 & 6.837 & 1.007 \\
\hline Europe & 55 & 224 & 3.500 & 3.900 & 4.000 & 3.800 & 0.692 \\
\hline - Public & 7 & 27 & 3.000 & 3.507 & 4.200 & 3.660 & 0.758 \\
\hline - Non-public & 48 & 197 & 3.600 & 3.990 & 4.000 & 3.819 & 0.682 \\
\hline
\end{tabular}


Table 2: Panel regressions: Percentage allocation to risky assets based on strategic asset allocation

In this table we estimate a panel model and the dependent variable is the percentage allocation to risky assets based on the strategic asset allocation of pension funds. The risky assets include allocations to equity, alternative asset classes (i.e., hedge funds, private equity and real estate), high yield bonds and mortgages. As independent variables we include \%Retired percentage of retired members from total pension fund members, Fund size - logarithm of total pension fund assets, Inflation protection - dummy variable taking value one if a fund provides a contractual inflation protection, Public - dummy variable taking value one if a pension fund is public, Public * U.S. - interaction term capturing U.S. public funds, \%Retired * Public interaction term capturing the percentage of retired members among public funds, \%Retired * Public * U.S. - interaction term capturing the percentage of retired members among U.S. public funds, Canada and Europe - regional dummy variables (the base result refers to U.S. funds). Where indicated we include year dummies and fund fixed effects. We independently double cluster the robust standard errors by pension fund and by year. We report standard errors in brackets and significance levels with *, ** and $* * *$, which correspond to $0.10,0.05$ and 0.01 , respectively.

\begin{tabular}{|c|c|c|c|c|c|c|c|c|}
\hline & (1) & (2) & (3) & (4) & (5) & (6) & (7) & (8) \\
\hline & \multicolumn{8}{|c|}{ Dependent variable: Percentage allocation to risky assets based on strategic asset allocation } \\
\hline \multirow[t]{2}{*}{ \%Retired } & $-0.079 * * *$ & $-0.089 * * *$ & $-0.092 * * *$ & $-0.117 * * *$ & $-0.116^{* * *}$ & $-0.131 * * *$ & $-0.137 * * *$ & $-0.144 * * *$ \\
\hline & {$[0.023]$} & {$[0.021]$} & {$[0.021]$} & {$[0.022]$} & {$[0.022]$} & {$[0.036]$} & {$[0.035]$} & {$[0.036]$} \\
\hline \multirow[t]{2}{*}{ Fund size } & $0.005 * *$ & $0.007 * * *$ & $0.007 * * *$ & $0.008 * * *$ & $0.009 * * *$ & 0.021 & 0.020 & 0.019 \\
\hline & {$[0.002]$} & {$[0.002]$} & {$[0.002]$} & {$[0.002]$} & {$[0.002]$} & [0.014] & {$[0.014]$} & {$[0.014]$} \\
\hline \multirow[t]{2}{*}{ Inflation protection } & -0.002 & 0.010 & 0.011 & 0.011 & 0.011 & & & \\
\hline & {$[0.007]$} & [0.007] & {$[0.007]$} & {$[0.007]$} & [0.007] & & & \\
\hline \multirow[t]{2}{*}{ Public } & & $-0.032 * *$ & -0.020 & $-0.066 * *$ & -0.030 & & & \\
\hline & & {$[0.014]$} & {$[0.014]$} & {$[0.029]$} & [0.029] & & & \\
\hline \multirow{2}{*}{ Public * U.S. } & & & -0.019 & -0.016 & $-0.127 * * *$ & & & \\
\hline & & & {$[0.017]$} & {$[0.016]$} & {$[0.045]$} & & & \\
\hline \multirow[t]{2}{*}{ \%Retired * Public } & & & & $0.117^{*}$ & 0.024 & & 0.089 & 0.015 \\
\hline & & & & [0.065] & {$[0.056]$} & & {$[0.065]$} & [0.068] \\
\hline \multirow[t]{2}{*}{ \%Retired * Public * U.S. } & & & & & $0.321 * * *$ & & & $0.253 * *$ \\
\hline & & & & & {$[0.111]$} & & & {$[0.125]$} \\
\hline \multirow[t]{2}{*}{ Canada } & $-0.071 * * *$ & $-0.075^{* * *}$ & $-0.082 * * *$ & $-0.082 * * *$ & $-0.082 * * *$ & & & \\
\hline & [0.007] & [0.008] & {$[0.010]$} & [0.010] & [0.010] & & & \\
\hline \multirow[t]{2}{*}{ Europe } & $-0.128 * * *$ & $-0.138 * * *$ & $-0.142 * * *$ & $-0.145^{* * *}$ & $-0.144 * * *$ & & & \\
\hline & [0.020] & [0.018] & [0.019] & [0.019] & [0.019] & & & \\
\hline Year dummies & Yes & Yes & Yes & Yes & Yes & Yes & Yes & Yes \\
\hline Fund-fixed effects & No & No & No & No & No & Yes & Yes & Yes \\
\hline Double clustering & Yes & Yes & Yes & Yes & Yes & Yes & Yes & Yes \\
\hline Observations & 4806 & 4806 & 4806 & 4806 & 4806 & 4821 & 4821 & 4821 \\
\hline $\mathrm{R}^{2}$ & 0.195 & 0.208 & 0.209 & 0.215 & 0.226 & 0.750 & 0.751 & 0.753 \\
\hline
\end{tabular}


Table 3: Panel regressions: Percentage allocation to risky assets based on strategic asset allocation by region

In this table we estimate a panel model and the dependent variable is the percentage allocation to risky assets based on the strategic asset allocation of pension funds. We present the results for U.S. funds in Panel A and Canadian funds in Panel B. As independent variables we include \%Retired - percentage of retired members from total pension fund members, Fund size logarithm of total pension fund assets, Inflation protection - dummy variable taking value one if a fund provides a contractual inflation protection, Public - dummy variable taking value one if a pension fund is public, and \%Retired * Public - interaction term capturing the percentage of retired members among public funds. Where indicated we include year dummies and fund fixed effects. We independently double cluster the robust standard errors by pension fund and by year. We report standard errors in brackets and significance levels with $*, * *$ and ***, which correspond to 0.10, 0.05 and 0.01, respectively.

\begin{tabular}{|c|c|c|c|c|c|}
\hline & $(1)$ & $(2)$ & (3) & $(4)$ & $(5)$ \\
\hline \multicolumn{6}{|c|}{ Panel A: U.S. pension funds } \\
\hline \%Retired & $\begin{array}{c}-0.076^{* *} \\
{[0.032]}\end{array}$ & $-0.100 * * *$ & $-0.143 * * *$ & $-0.157 * * *$ & $-0.176^{* * *}$ \\
\hline Fund size & $\begin{array}{c}0.002 \\
{[0.003]}\end{array}$ & $\begin{array}{c}0.005^{*} \\
{[0.003]}\end{array}$ & $\begin{array}{c}0.008^{* * *} \\
{[0.003]}\end{array}$ & $\begin{array}{c}{[0.040]} \\
0.027 \\
{[0.020]}\end{array}$ & $\begin{array}{c}{[0.04 /]} \\
0.019 \\
{[0.019]}\end{array}$ \\
\hline Inflation protection & $\begin{array}{c}-0.000 \\
{[0.010]}\end{array}$ & $\begin{array}{l}0.023^{* *} \\
{[0.012]}\end{array}$ & $\begin{array}{c}0.024 * * \\
{[0.012]}\end{array}$ & & \\
\hline Public & & $\begin{array}{c}-0.044 * * \\
{[0.019]}\end{array}$ & $\begin{array}{c}-0.176^{* * *} \\
{[0.049]}\end{array}$ & & \\
\hline \%Retired * Public & & & $\begin{array}{c}0.374 * * * \\
{[0.110]}\end{array}$ & & $\begin{array}{l}0.286^{* *} \\
{[0.114]}\end{array}$ \\
\hline Year dummies & Yes & Yes & Yes & Yes & Yes \\
\hline Fund-fixed effects & No & No & No & Yes & Yes \\
\hline Double clustering & Yes & Yes & Yes & Yes & Yes \\
\hline Observations & 2919 & 2919 & 2919 & 2932 & 2932 \\
\hline $\mathrm{R}^{2}$ & 0.065 & 0.088 & 0.120 & 0.704 & 0.710 \\
\hline \multicolumn{6}{|c|}{ Panel B: Canadian pension funds } \\
\hline \%Retired & $\begin{array}{c}-0.091 * * * \\
{[0.029]}\end{array}$ & $\begin{array}{c}-0.090 * * * \\
{[0.028]}\end{array}$ & $\begin{array}{c}-0.083 * * * \\
{[0.027]}\end{array}$ & $\begin{array}{l}-0.078^{*} \\
{[0.042]}\end{array}$ & $\begin{array}{l}-0.078^{*} \\
{[0.041]}\end{array}$ \\
\hline Fund size & $\begin{array}{c}0.006 \\
{[0.005]}\end{array}$ & $\begin{array}{c}0.008 \\
{[0.005]}\end{array}$ & $\begin{array}{c}0.007 \\
{[0.005]}\end{array}$ & $\begin{array}{c}0.015 \\
{[0.026]}\end{array}$ & $\begin{array}{c}0.015 \\
{[0.025]}\end{array}$ \\
\hline Inflation protection & $\begin{array}{l}-0.003 \\
{[0.009]}\end{array}$ & $\begin{array}{c}-0.001 \\
{[0.010]}\end{array}$ & $\begin{array}{c}-0.002 \\
{[0.010]}\end{array}$ & & \\
\hline Public & & $\begin{array}{c}-0.015 \\
{[0.015]}\end{array}$ & $\begin{array}{c}-0.007 \\
{[0.033]}\end{array}$ & & \\
\hline \%Retired * Public & & & $\begin{array}{c}-0.019 \\
{[0.064]}\end{array}$ & & $\begin{array}{c}0.004 \\
{[0.062]}\end{array}$ \\
\hline Year dummies & Yes & Yes & Yes & Yes & Yes \\
\hline Fund-fixed effects & No & No & No & Yes & Yes \\
\hline Double clustering & Yes & Yes & Yes & Yes & Yes \\
\hline Observations & 1619 & 1619 & 1619 & 1621 & 1621 \\
\hline $\mathrm{R}^{2}$ & 0.149 & 0.154 & 0.154 & 0.701 & 0.701 \\
\hline
\end{tabular}


Table 4: Percentage allocation to risky assets and controlling for previous year treasury yield

In this table we estimate a panel model and the dependent variable is the percentage allocation to risky assets based on the strategic asset allocation of pension funds. The risky assets include allocations to equity, alternative asset classes (i.e., hedge funds, private equity and real estate), high yield bonds and mortgages. Compared to previous results we control for Treasury yield $(\mathrm{t}-1)$ - treasury yield in the previous year, Public * Yield (t-1) - interaction term capturing the effect of previous year treasury yield on public funds, and Public * Yield (t-1) * U.S. - interaction terms capturing the effect of previous year treasury yield on U.S. public funds. As independent variables we include Fund size - logarithm of total pension fund assets, Inflation protection dummy variable taking value one if a fund provides a contractual inflation protection, \%Retired - percentage of retired members from total pension fund members, Public - dummy variable taking value one if a pension fund is public, Public * U.S. interaction term capturing U.S. public funds, Canada and Europe - regional dummy variables (the base result refers to U.S. funds). Where indicated we include year dummies and fund fixed effects. We double cluster the standard errors by pension fund and by year. We report standard errors in brackets and significance levels with *,** and ***, which correspond to $0.10,0.05$ and 0.01 , respectively.

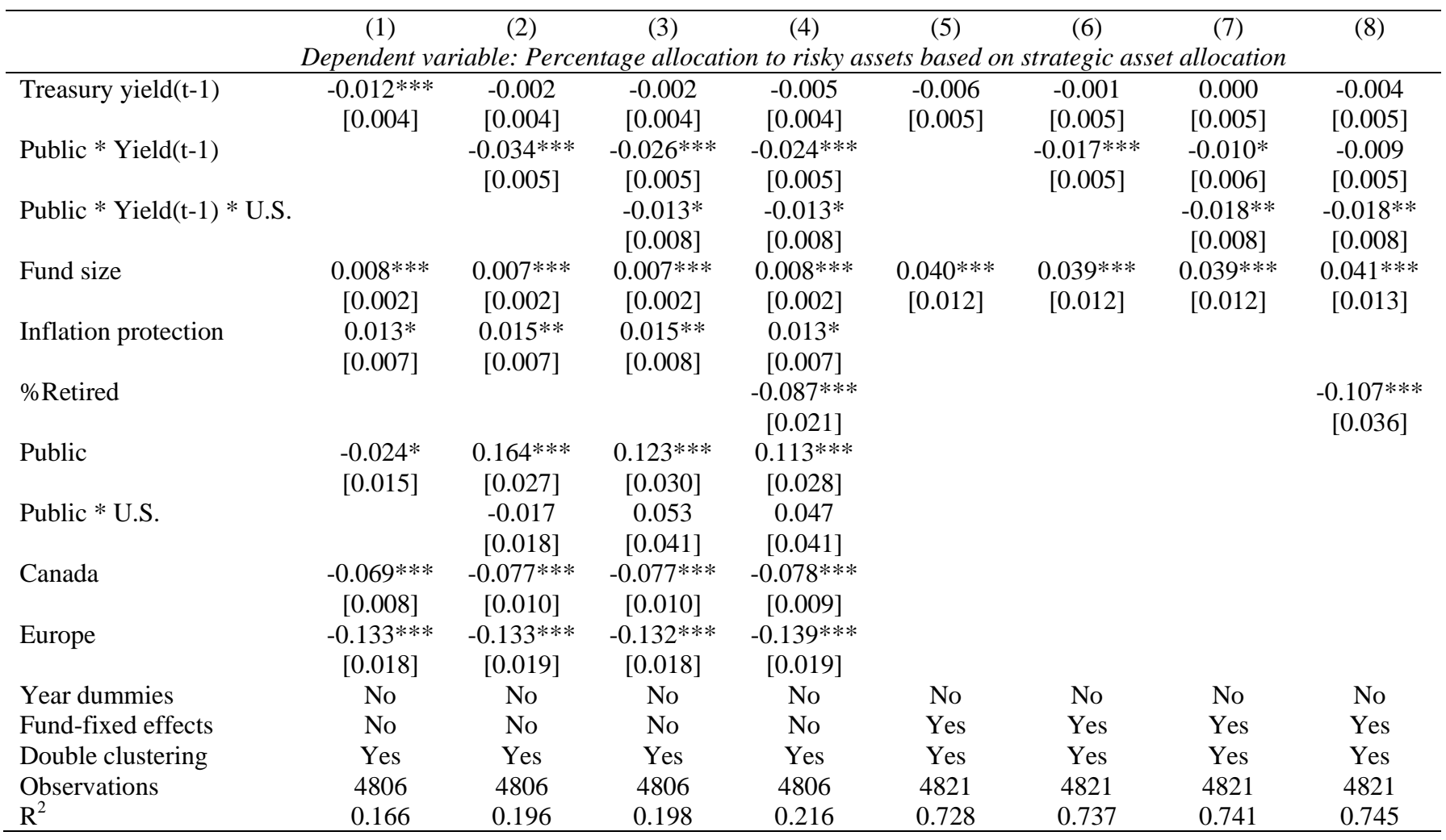




\section{Table 5: Regression results: Liability discount rates}

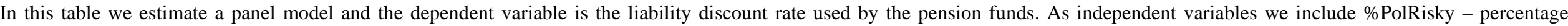

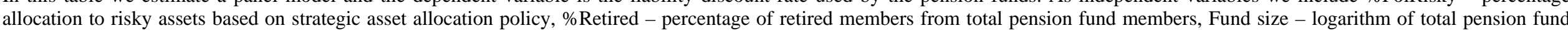

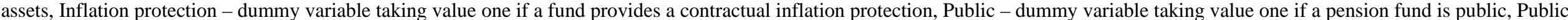

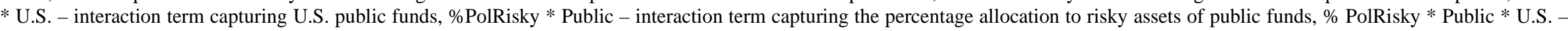

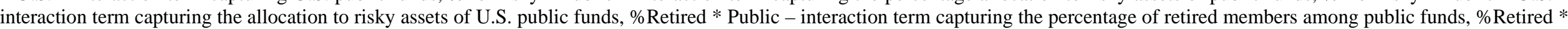

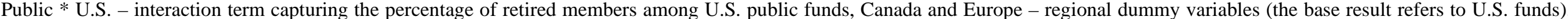

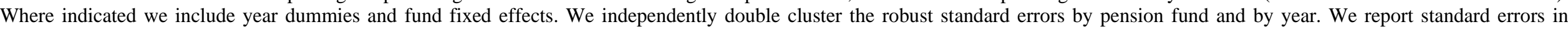
brackets and significance levels with $*, * *$ and $* * *$, which correspond to $0.10,0.05$ and 0.01 , respectively.

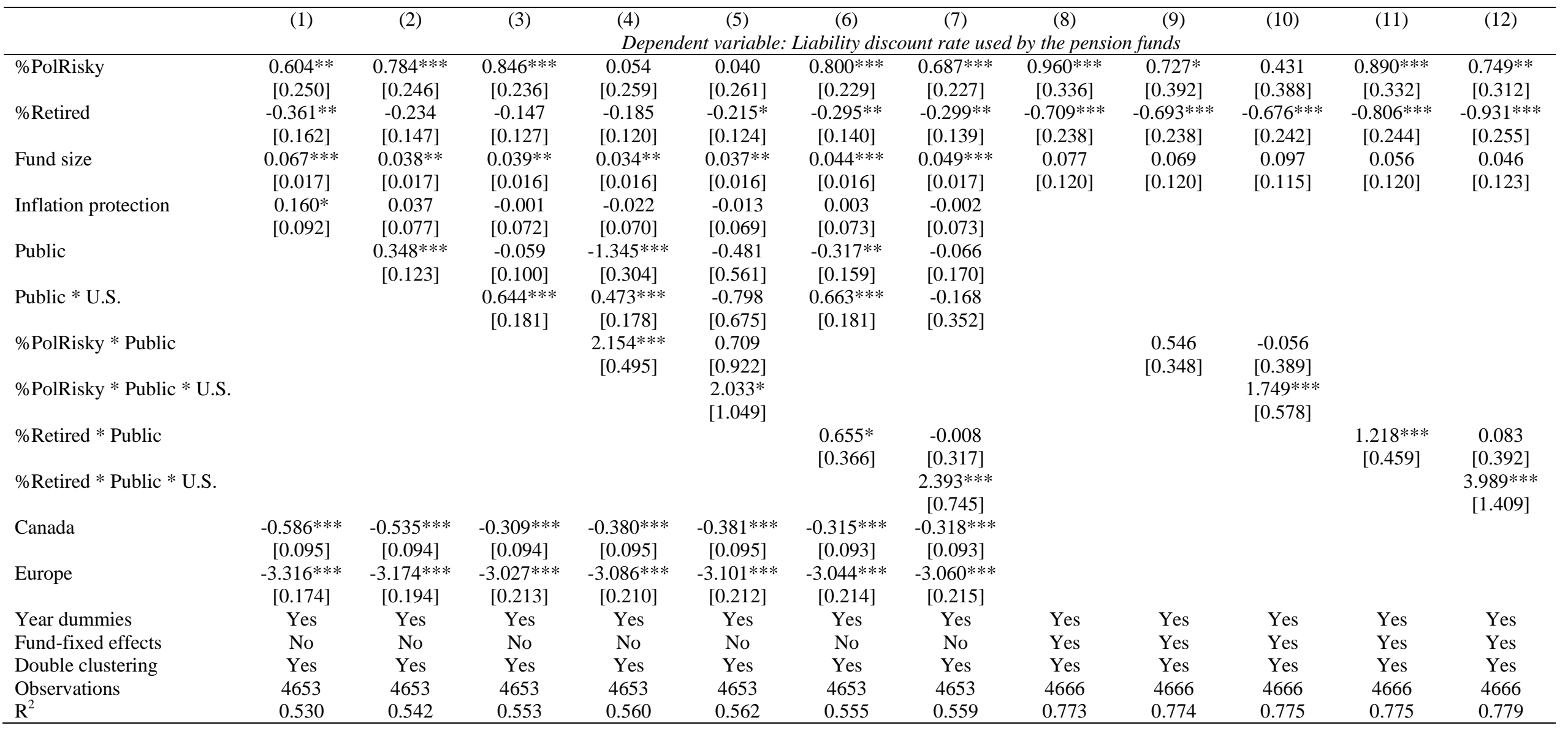


Table 6: Regression results: Liability discount rates and treasury yields

In this table we estimate a panel model and the dependent variable is the liability discount rate used by the pension funds. We control for Treasury yield - 10 year treasury yield, Public * Yield - interaction term capturing the effect of treasury yield on public funds, and Public * Yield * U.S. - interaction terms capturing the effect of treasury yield on U.S. public funds. As independent variables we also include \%PolRisky - percentage strategic allocation to risky assets, \%Retired - percentage of retired members from total pension fund members, Fund size - logarithm of total pension fund assets, Inflation protection dummy variable taking value one if a fund provides a contractual inflation protection, Public - dummy variable taking value one if a pension fund is public, Public * U.S. - interaction term capturing U.S. public funds, \%PolRisky * Public - interaction term capturing the percentage allocation to risky assets of public funds, \% PolRisky * Public * U.S. - interaction term capturing the allocation to risky assets of U.S. public funds, \%Retired * Public - interaction term capturing the percentage of retired members among public funds, \%Retired * Public * U.S. - interaction term capturing the percentage of retired members among U.S. public funds, Canada and Europe - regional dummy variables (the base result refers to U.S. funds). Where indicated we include year dummies and fund fixed effects. We independently double cluster the robust standard errors by pension fund and by year. We report standard errors in brackets and significance levels with *, ** and ***, which correspond to 0.10 , 0.05 and 0.01 , respectively.

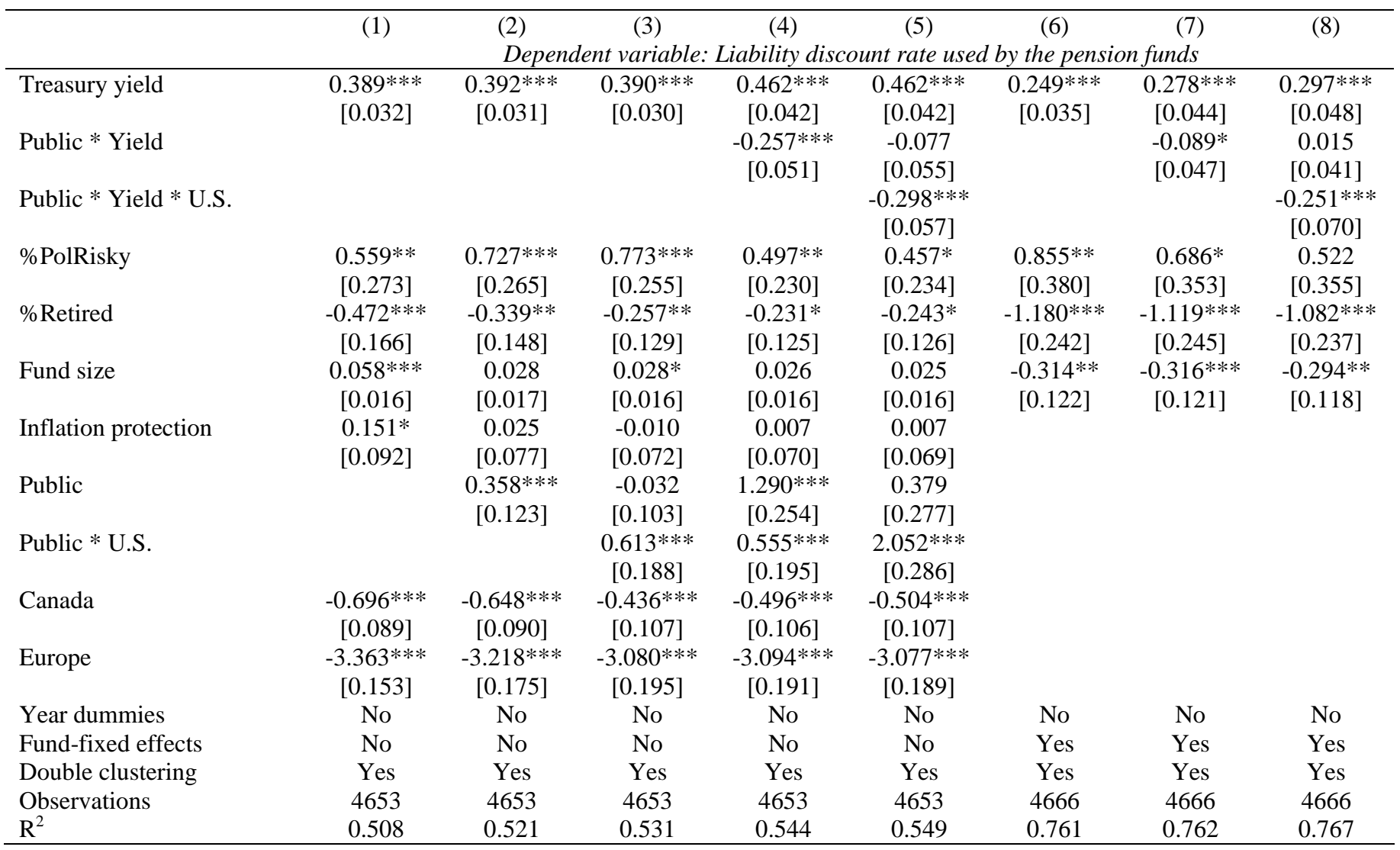


Table 7: Panel regressions: Liability discount rates by region

In this table we estimate a panel model and the dependent variable is the percentage allocation to risky assets based on the strategic asset allocation of pension funds. We present the results separately for U.S. funds in columns (1) to (4) and Canadian funds in columns (5) to (8). As independent variables we include \%Retired - percentage of retired members from total pension fund members, Fund size - logarithm of total pension fund assets, Inflation protection - dummy variable taking value one if a fund provides a contractual inflation protection, Public - dummy variable taking value one if a pension fund is public, and \%Retired * Public - interaction term capturing the percentage of retired members among public funds. Where indicated we include year dummies and fund fixed effects. We independently double cluster the robust standard errors by pension fund and by year. We report standard errors in brackets and significance levels with *,** and ***, which correspond to $0.10,0.05$ and 0.01 , respectively.

\begin{tabular}{|c|c|c|c|c|c|c|c|c|}
\hline & $\begin{array}{l}\text { (1) } \\
\text { U.S. }\end{array}$ & $\begin{array}{l}\text { (2) } \\
\text { U.S. }\end{array}$ & $\begin{array}{l}\text { (3) } \\
\text { U.S. }\end{array}$ & $\begin{array}{l}\text { (4) } \\
\text { U.S. }\end{array}$ & $\begin{array}{c}\text { (5) } \\
\text { Canada }\end{array}$ & $\begin{array}{c}(6) \\
\text { Canada }\end{array}$ & $\begin{array}{c}(7) \\
\text { Canada }\end{array}$ & $\begin{array}{c}(8) \\
\text { Canada }\end{array}$ \\
\hline Treasury yield & $\begin{array}{c}0.580 * * * \\
{[0.055]}\end{array}$ & $\begin{array}{c}0.575 * * * \\
{[0.054]}\end{array}$ & $\begin{array}{c}0.410 * * * \\
{[0.072]}\end{array}$ & $\begin{array}{c}0.394 * * * \\
{[0.071]}\end{array}$ & $\begin{array}{c}0.358 * * * \\
{[0.040]}\end{array}$ & $\begin{array}{c}0.369 * * * \\
{[0.041]}\end{array}$ & $\begin{array}{c}0.215^{* * *} \\
{[0.051]}\end{array}$ & $\begin{array}{c}0.214^{* * *} \\
{[0.052]}\end{array}$ \\
\hline Public * Yield & $\begin{array}{c}-0.467 * * * \\
{[0.061]}\end{array}$ & $\begin{array}{c}-0.455^{* * *} \\
{[0.060]}\end{array}$ & $\begin{array}{c}-0.329 * * * \\
{[0.084]}\end{array}$ & $\begin{array}{c}-0.308^{* * *} \\
{[0.077]}\end{array}$ & $\begin{array}{c}0.042 \\
{[0.048]}\end{array}$ & $\begin{array}{c}0.001 \\
{[0.047]}\end{array}$ & $\begin{array}{c}0.034 \\
{[0.046]}\end{array}$ & $\begin{array}{c}0.037 \\
{[0.048]}\end{array}$ \\
\hline \%PolRisky & $\begin{array}{c}0.215 \\
{[0.276]}\end{array}$ & $\begin{array}{l}0.402^{*} \\
{[0.222]}\end{array}$ & $\begin{array}{c}-0.073 \\
{[0.525]}\end{array}$ & $\begin{array}{c}0.362 \\
{[0.394]}\end{array}$ & $\begin{array}{c}-0.196 \\
{[0.457]}\end{array}$ & $\begin{array}{c}0.220 \\
{[0.558]}\end{array}$ & $\begin{array}{c}-0.097 \\
{[0.579]}\end{array}$ & $\begin{array}{c}-0.088 \\
{[0.435]}\end{array}$ \\
\hline \%Retired & $\begin{array}{c}-0.487 * * * \\
{[0.154]}\end{array}$ & $\begin{array}{c}-0.636^{* * *} \\
{[0.144]}\end{array}$ & $\begin{array}{c}-1.150^{* * *} \\
{[0.324]}\end{array}$ & $\begin{array}{c}-1.450 * * * \\
{[0.340]}\end{array}$ & $\begin{array}{c}-0.105 \\
{[0.218]}\end{array}$ & $\begin{array}{c}0.077 \\
{[0.260]}\end{array}$ & $\begin{array}{c}-0.617 * \\
{[0.317]}\end{array}$ & $\begin{array}{c}-0.615^{*} \\
{[0.319]}\end{array}$ \\
\hline Fund size & $\begin{array}{c}0.053 * * * \\
{[0.017]}\end{array}$ & $\begin{array}{c}0.065^{* * *} \\
{[0.018]}\end{array}$ & $\begin{array}{c}-0.301^{* *} \\
{[0.152]}\end{array}$ & $\begin{array}{c}-0.342 * * \\
{[0.149]}\end{array}$ & $\begin{array}{c}0.007 \\
{[0.036]}\end{array}$ & $\begin{array}{c}0.012 \\
{[0.036]}\end{array}$ & $\begin{array}{c}-0.451^{* *} \\
{[0.206]}\end{array}$ & $\begin{array}{c}-0.450^{* *} \\
{[0.204]}\end{array}$ \\
\hline Inflation protection & $\begin{array}{c}0.077 \\
{[0.095]}\end{array}$ & $\begin{array}{c}0.087 \\
{[0.095]}\end{array}$ & & & $\begin{array}{c}-0.104 \\
{[0.099]}\end{array}$ & $\begin{array}{c}-0.095 \\
{[0.103]}\end{array}$ & & \\
\hline Public & $\begin{array}{c}2.251^{* * *} \\
{[0.488]}\end{array}$ & $\begin{array}{c}2.229 * * * \\
{[0.439]}\end{array}$ & & & $\begin{array}{c}-0.934 \\
{[0.770]}\end{array}$ & $\begin{array}{c}0.192 \\
{[0.322]}\end{array}$ & & \\
\hline \%PolRisky * Public & $\begin{array}{l}0.818^{*} \\
{[0.486]}\end{array}$ & & $\begin{array}{c}1.444 \\
{[0.935]}\end{array}$ & & $\begin{array}{c}1.193 \\
{[1.130]}\end{array}$ & & $\begin{array}{c}0.005 \\
{[0.506]}\end{array}$ & \\
\hline \%Retired * Public & & $\begin{array}{l}1.474^{* *} \\
{[0.579]}\end{array}$ & & $\begin{array}{c}3.724 * * * \\
{[1.122]}\end{array}$ & & $\begin{array}{c}-0.511 \\
{[0.457]}\end{array}$ & & $\begin{array}{c}-0.049 \\
{[0.470]}\end{array}$ \\
\hline Year dummies & No & No & No & No & No & No & No & No \\
\hline Fund-fixed effects & No & No & Yes & Yes & No & No & Yes & Yes \\
\hline Double clustering & Yes & Yes & Yes & Yes & Yes & Yes & Yes & Yes \\
\hline Observations & 2854 & 2854 & 2865 & 2865 & 1575 & 1575 & 1577 & 1577 \\
\hline $\mathrm{R}^{2}$ & 0.339 & 0.343 & 0.642 & 0.650 & 0.305 & 0.305 & 0.667 & 0.667 \\
\hline
\end{tabular}




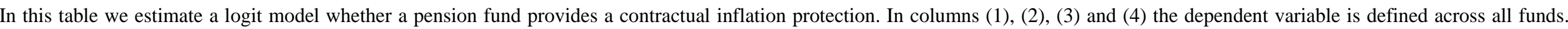

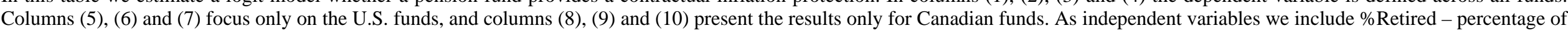

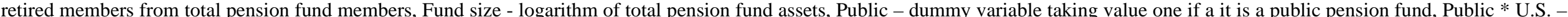

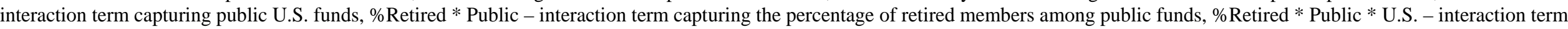

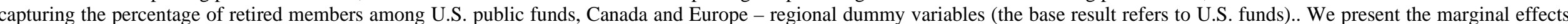

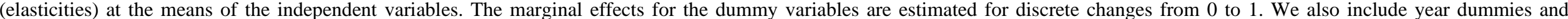
independently double cluster the robust standard errors by pension fund and by year.

\begin{tabular}{|c|c|c|c|c|c|c|c|c|c|c|}
\hline & $\begin{array}{c}\text { (1) } \\
\text { All funds }\end{array}$ & $\begin{array}{c}\text { (2) } \\
\text { All funds }\end{array}$ & $\begin{array}{c}\text { (3) } \\
\text { All funds }\end{array}$ & $\begin{array}{c}\text { (4) } \\
\text { All funds }\end{array}$ & $\begin{array}{l}\text { (5) } \\
\text { U.S. }\end{array}$ & $\begin{array}{l}\text { (6) } \\
\text { U.S. }\end{array}$ & $\begin{array}{l}\text { (7) } \\
\text { U.S. }\end{array}$ & $\begin{array}{c}(8) \\
\text { Canada }\end{array}$ & $\begin{array}{c}(9) \\
\text { Canada }\end{array}$ & $\begin{array}{c}\text { (10) } \\
\text { Canada }\end{array}$ \\
\hline \%Retired & $\begin{array}{c}-0.409^{* * *} \\
{[0.102]}\end{array}$ & $\begin{array}{c}-0.287 * * \\
{[0.134]}\end{array}$ & $\begin{array}{l}-0.213^{*} \\
{[0.119]}\end{array}$ & $\begin{array}{c}-0.189 \\
{[0.129]}\end{array}$ & $\begin{array}{c}-0.554 * * * \\
{[0.115]}\end{array}$ & $\begin{array}{c}-0.216^{*} \\
{[0.115]}\end{array}$ & $\begin{array}{l}-0.218^{*} \\
{[0.134]}\end{array}$ & $\begin{array}{c}-0.263 \\
{[0.191]}\end{array}$ & $\begin{array}{c}-0.274 \\
{[0.202]}\end{array}$ & $\begin{array}{c}-0.204 \\
{[0.238]}\end{array}$ \\
\hline Fund size & $\begin{array}{c}0.056^{* * *} \\
{[0.015]}\end{array}$ & $\begin{array}{c}0.018 \\
{[0.016]}\end{array}$ & $\begin{array}{c}0.016 \\
{[0.015]}\end{array}$ & $\begin{array}{c}0.016 \\
{[0.015]}\end{array}$ & $\begin{array}{c}0.028 * \\
{[0.018]}\end{array}$ & $\begin{array}{c}-0.020 \\
{[0.015]}\end{array}$ & $\begin{array}{c}-0.020 \\
{[0.015]}\end{array}$ & $\begin{array}{c}0.132 * * * \\
{[0.031]}\end{array}$ & $\begin{array}{c}0.120 * * * \\
{[0.032]}\end{array}$ & $\begin{array}{c}0.119 * * * \\
{[0.032]}\end{array}$ \\
\hline Public & & $\begin{array}{c}0.417 * * * \\
{[0.054]}\end{array}$ & $\begin{array}{c}0.198 * * * \\
{[0.077]}\end{array}$ & $\begin{array}{c}0.244 \\
{[0.165]}\end{array}$ & & $\begin{array}{c}0.464 * * * \\
{[0.050]}\end{array}$ & $\begin{array}{c}0.461 * * * \\
{[0.125]}\end{array}$ & & $\begin{array}{c}0.187 * * \\
{[0.095]}\end{array}$ & $\begin{array}{c}0.256 \\
{[0.176]}\end{array}$ \\
\hline Public * U.S. & & & $\begin{array}{c}0.378 * * * \\
{[0.103]}\end{array}$ & $\begin{array}{c}0.326 \\
{[0.205]}\end{array}$ & & & & & & \\
\hline \%Retired * Public & & & & $\begin{array}{c}-0.105 \\
{[0.309]}\end{array}$ & & & $\begin{array}{c}0.006 \\
{[0.229]}\end{array}$ & & & $\begin{array}{c}-0.190 \\
{[0.398]}\end{array}$ \\
\hline \%Ret. * Public * U.S. & & & & $\begin{array}{c}0.118 \\
{[0.389]}\end{array}$ & & & & & & \\
\hline Canada & $\begin{array}{c}0.353^{* * *} \\
{[0.053]}\end{array}$ & $\begin{array}{c}0.409 * * * \\
{[0.058]}\end{array}$ & $\begin{array}{c}0.541^{* * *} \\
{[0.061]}\end{array}$ & $\begin{array}{c}0.541^{* * *} \\
{[0.061]}\end{array}$ & & & & & & \\
\hline Europe & $\begin{array}{c}-0.104 \\
{[0.071]}\end{array}$ & $\begin{array}{c}0.063 \\
{[0.105]}\end{array}$ & $\begin{array}{c}0.230 * * \\
{[0.113]}\end{array}$ & $\begin{array}{c}0.232 * * \\
{[0.114]}\end{array}$ & & & & & & \\
\hline Year dummies & Yes & Yes & Yes & Yes & Yes & Yes & Yes & Yes & Yes & Yes \\
\hline Double clustering & Yes & Yes & Yes & Yes & Yes & Yes & Yes & Yes & Yes & Yes \\
\hline Observations & 4806 & 4806 & 4806 & 4806 & 2918 & 2918 & 2918 & 1618 & 1618 & 1618 \\
\hline Pseudo $\mathrm{R}^{2}$ & 0.097 & 0.199 & 0.218 & 0.218 & 0.021 & 0.272 & 0.272 & 0.088 & 0.105 & 0.106 \\
\hline
\end{tabular}


Figure 1: Percentage retired members (\%Ret) and percentage allocation to risky assets (\%Risky) by region and plan type

U.S. funds: Percentage allocation to risky assets and percentage retired members

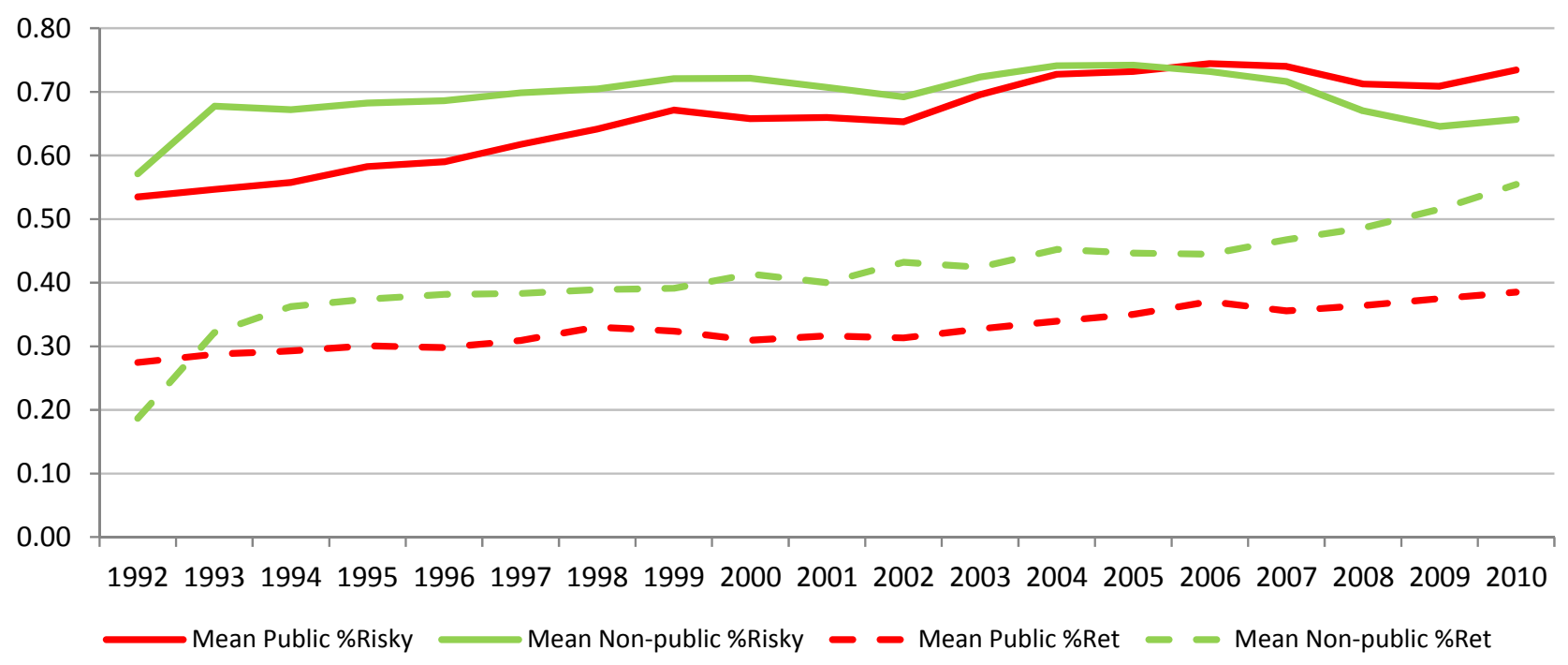

Canadian funds: Percentage allocation to risky assets and percentage retired members

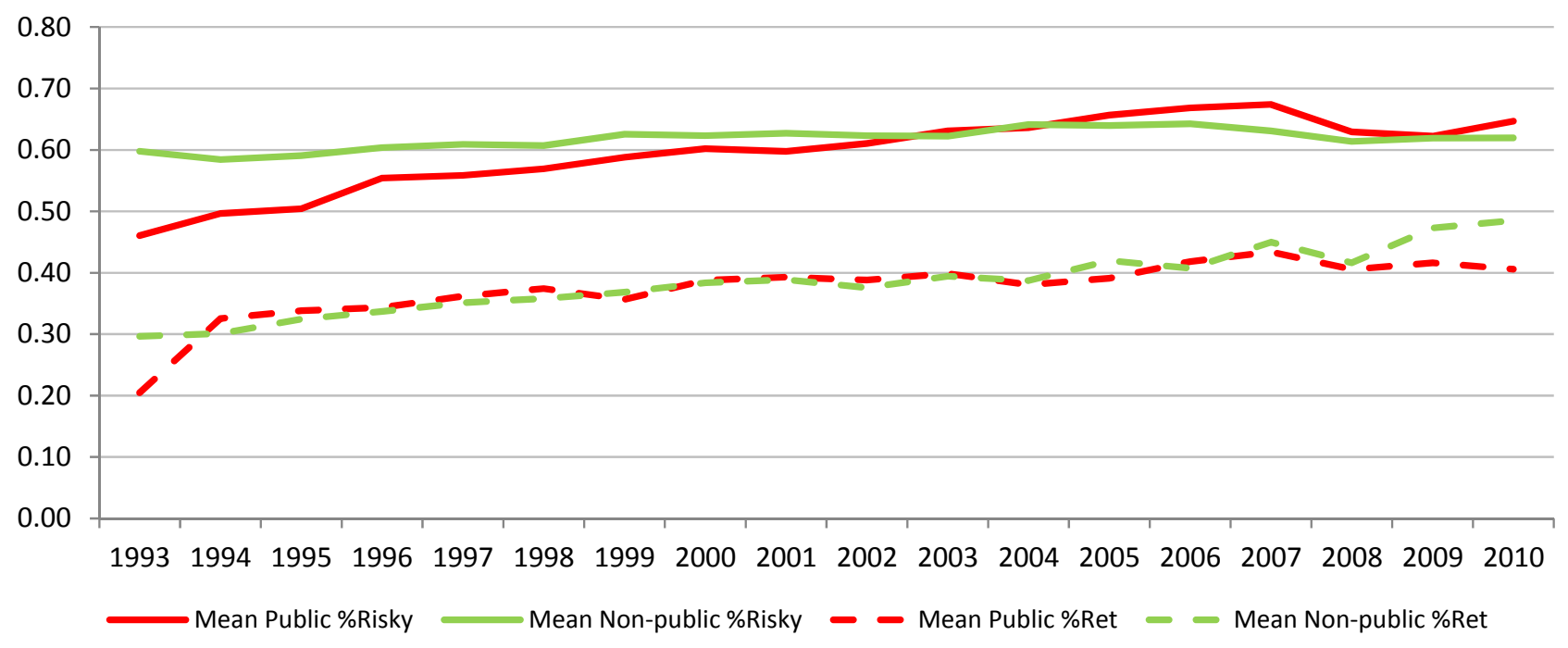

European funds: Percentage allocation to risky assets and percentage retired members

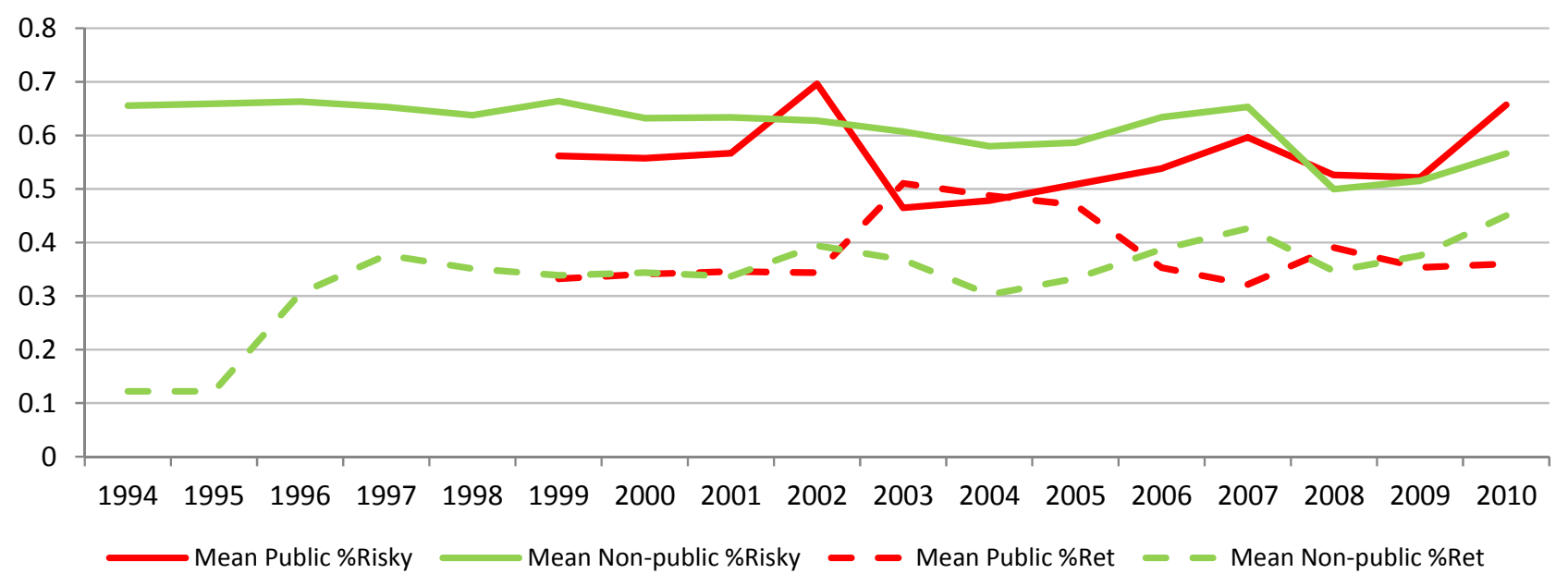


Figure 2: Liability discount rates (LDR) and Treasury yields

U.S. funds: Liability discount rates (LDR) and ten-year Treasury yield

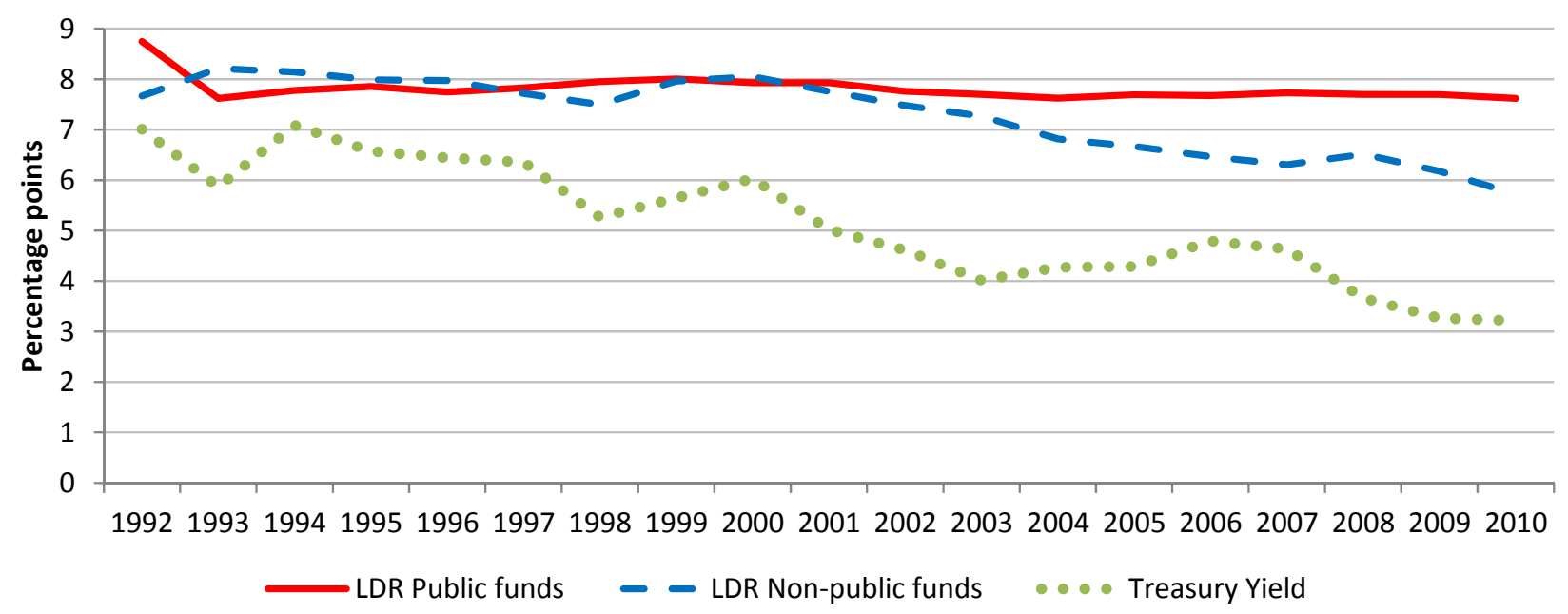

Canadian funds: Liability discount rates (LDR) and ten-year Treasury yield

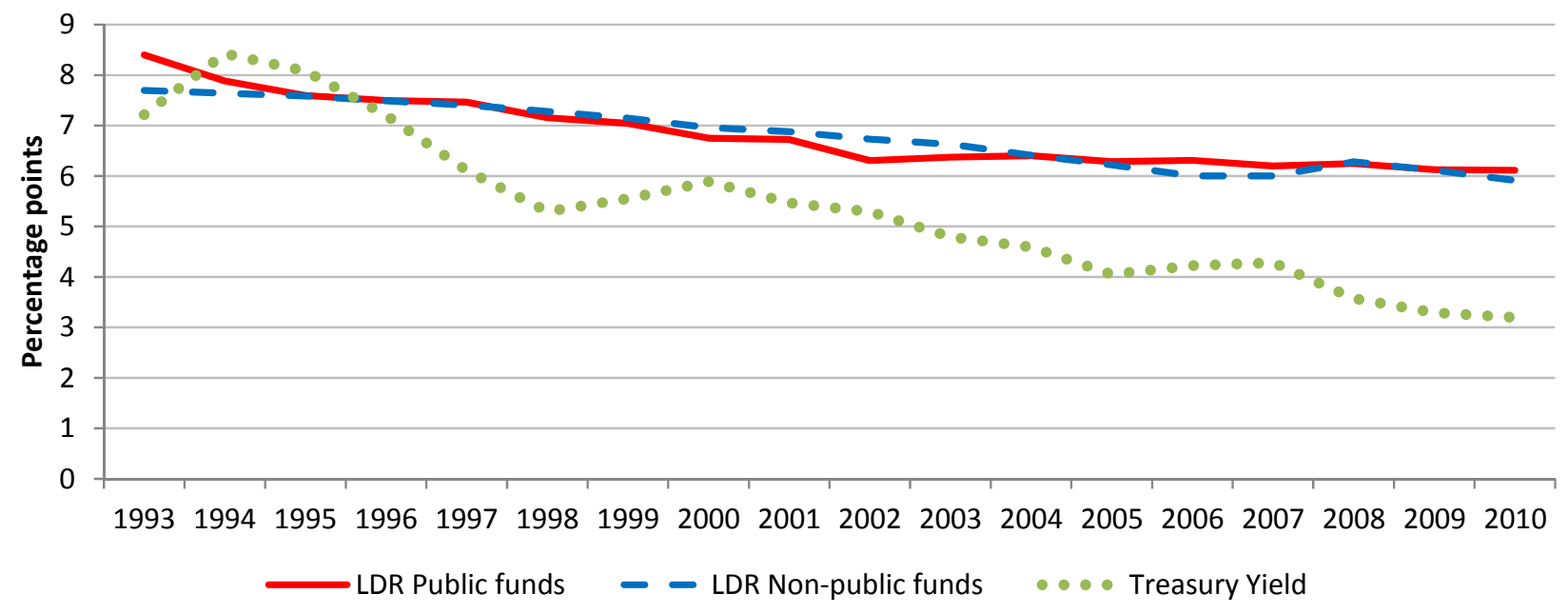

European funds: Liability discount rates (LDR) and ten-year Treasury yield

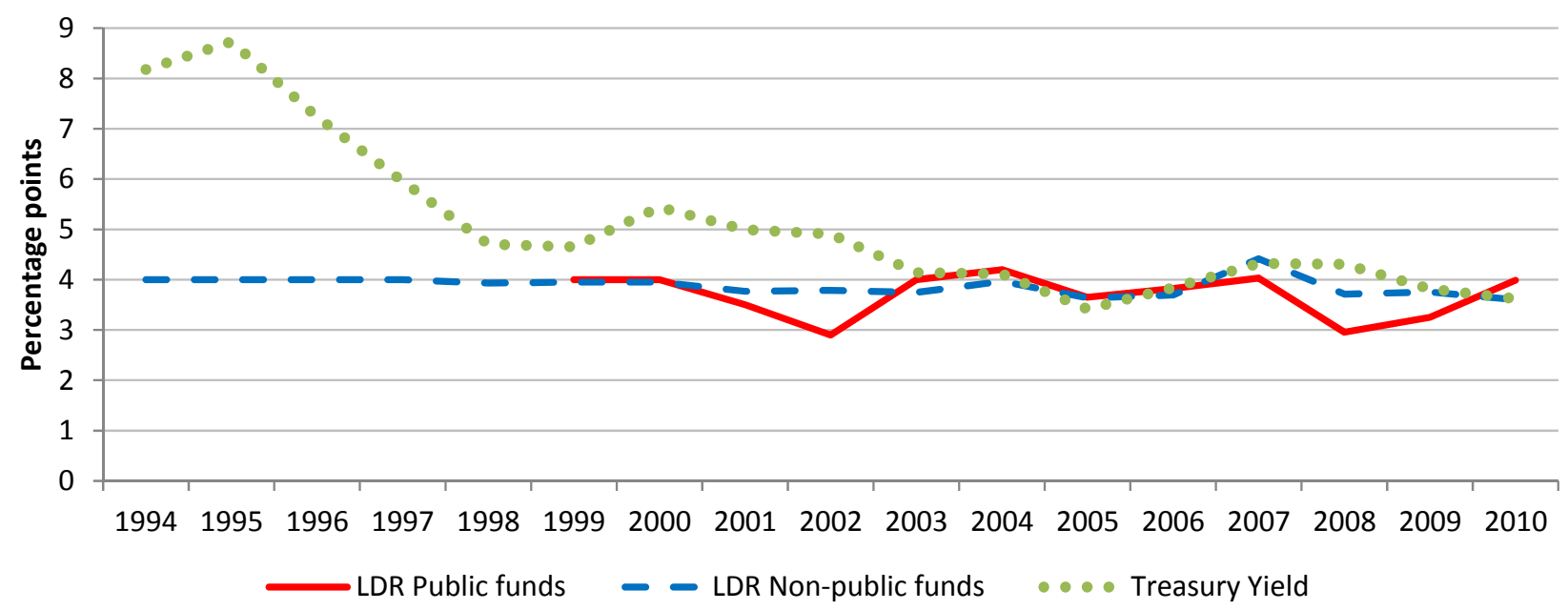

